\section{Energy and Water Use in Irrigated Agriculture During Drought Conditions}

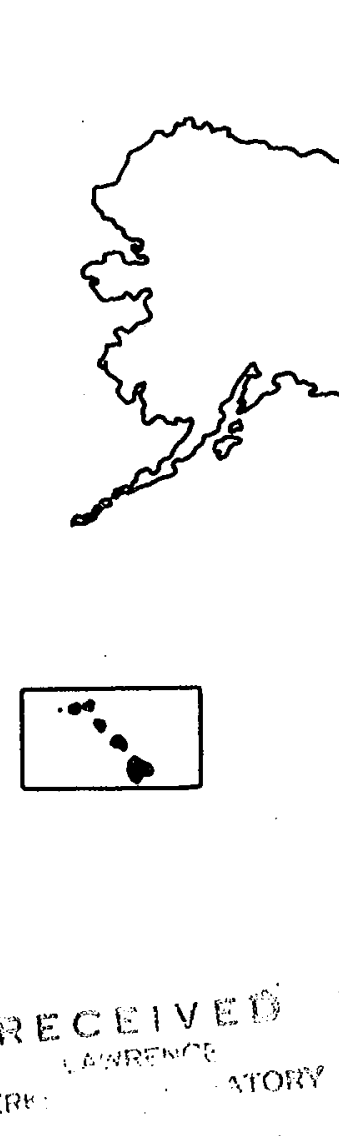

DEC 121978 JUNE 1978

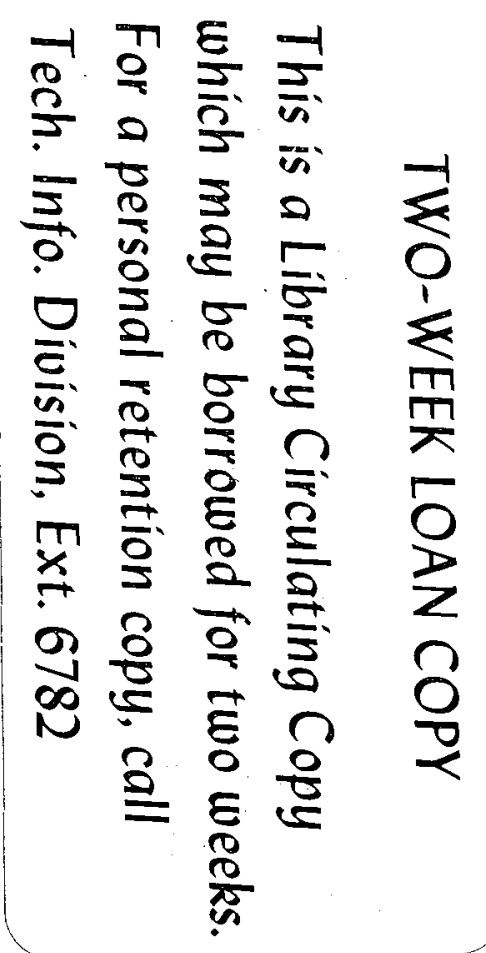

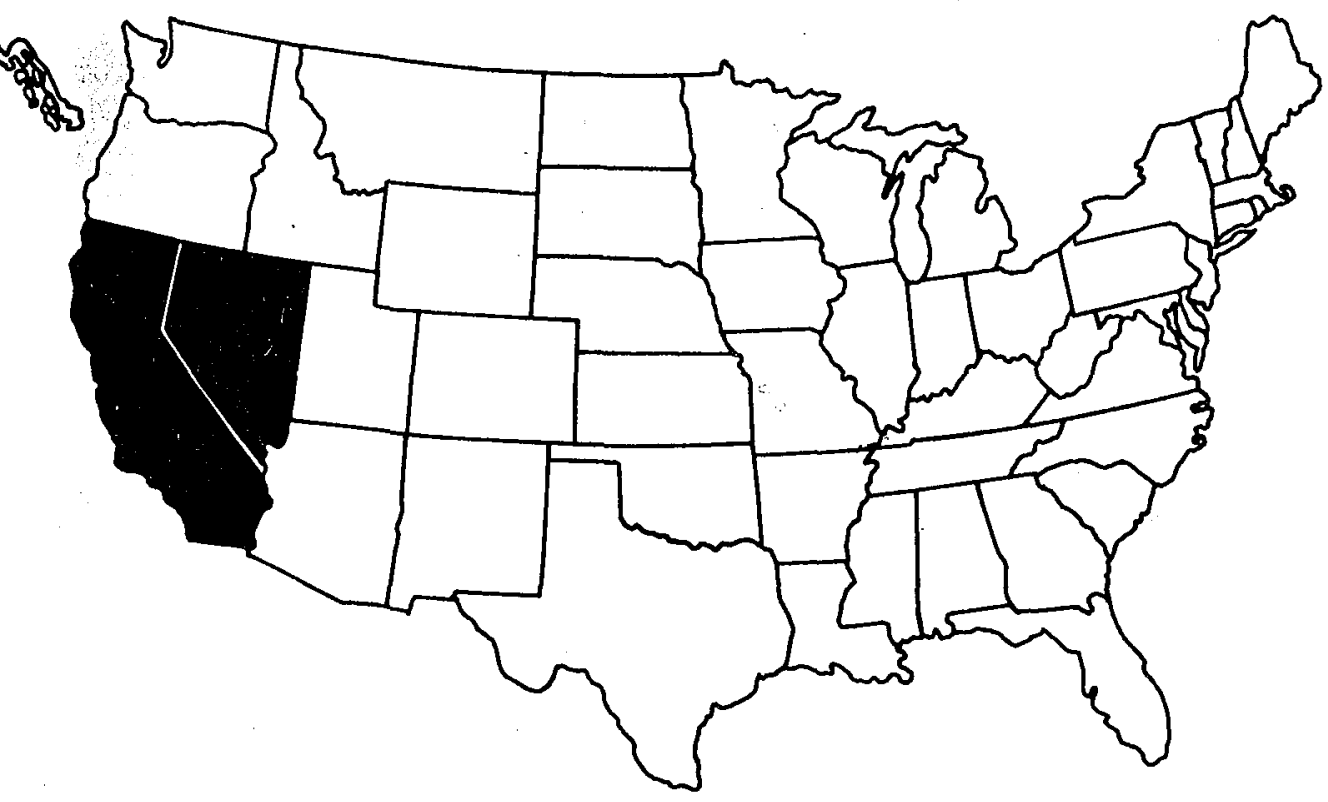

vi) 


\section{LEGAL NOTICE}

This report was prepared as an account of work sponsored by the United States Government. Neither the United States nor the Department of Energy, nor any of their employees, nor any of their contractors, subcontractors, or their employees, makes any warranty, express or implied, or assumes any legal liability or responsibility for the accuracy, completeness or usefulness of any information, apparatus, product or process disclosed, or represents that its use would not infringe privately owned rights.

Printed in the United States of America

$$
\text { Avilable from }
$$

National Technical Information Service U. S. Department of Commerce

5285 Port Royal Road

Springfield, VA 22161

Price: Printed Copy, \$ 5.25 Domestic; $\$ 10.50$ Foreign Microfiche, \$3.00 Domestic; \$4.50 Foreign 
LBL 7866

Energy \& Water Use in Irrigated Agriculture

During Drought Conditions

Ronald L. Ritschard and Karen Tsao

June 1978

Energy Analysis Program Energy and Environment Division Lawrence Berkeley Laboratory Berkeley, California 94720 

Acknow 1edgements

The authors wish to thank all the individuals and organizations who provided us with data, advice and insight into the problems associated with energy and water use in irrigated agriculture. In particular, we thank the following individuals who reviewed the manuscript and provided useful comments and suggestions: Peter Benenson (LBL), Vashek Cervinka (Ca1ifornia Department of Food and Agriculture), Robert Hagan (U. C. Davis); Phillip LaVeen (U.C. Berkeley), Daniel Piper (U.S. Department of Agriculture), Ed Roberts (U.C. Davis), Kenneth Turner (California Department of Water Resources), and W.R.Z. Willey (Environmental Defense Fund). In addition, we wish also to thank Gene Bolster and Cameron Applegate of the E1 Dorado Irrigation District and Gordon Lyford (U.S. Bureau of Reclamation) who provided the data on Irrigation Management Service found in Appendix A.

Special thanks for secretarial assistance go to Sharron Zeleke and Kay Gonick.

Work supported by the U.S. Department of Energy. 

Table of Contents

Acknowledgment. . . . . . . . . . . . . . $\frac{\text { Page }}{\text { iii }}$
Table of Contents. . . . . . . . . . . . . iv-v
List of Tables... . . . . . . . . . . vi
List of Figures. . . . . . . . . . . . vii
Summary. . . . . . . . . . . . . viii-ix

Page

INTRODUCTION . . . . . . . . . . . . . . . . . . . . . . . . 1

ENERGY/WATER USE DURING A DROUGHT YEAR (1977). . . . . . . . 2

Water Supply \& Demand in 1977. . . . . . . . . . . . . . . . 2

Energy Requirements for Agricultural Water Demands . . . . 7

Unit Water Use by Crop . . . . . . . . . . . . . . 11

Unit Energy Use by Crop. . . . . . . . . . . . . . 11

Estimate Crop Acreage in the Central Valley. . . . . . 13

Energy Demand for Agricultural Pumping in the Central

Valley . . . . . . . . . . . . . . . . . 16

AGRICULTURE'S RESPONSES TO THE DROUGHT CONDITIONS OF 1977. • 23

Increased Use of Ground Water. . . . . . . . . . . . . 23

Increased Efficiency of Water Application. . . . . . . . . 24

Reduce Water Application . . . . . . . . . . . . . 24

Cropping Pattern Changes in 1977 . . . . . . . . . . . 25

Future Problems Created During the Drought . . . . . . . 26

CONSERVATION OF ELECTRICITY \& WATER IN THE AGRICULTURE

SECTOR . . . . . . . . . . . . . . . . . . . 30

Factors in Agricultural Resource Use . . . . . . . . . . 30

Types of Strategies. . . . . . . . . . . . . . . 31

Maintaining and Augmenting Surface Water Supply. . . . . . 33

Reducing Evaporation and Percolation Losses. . . . . 33

Using Reclaimed Waste Water. . . . . . . . . . 36

Decrease in Electricity Demand . . . . . . . . . . . 36

Changing Pump Power Source . . . . . . . . . . . . 36

Power Use Efficiency . . . . . . . . . . . . . . . . . 38

We11 Efficiency \& Maintenance. . . . . . . . . . 38

Pump Efficiency \& Maintenance. . . . . . . . . . . 38 
Table of Contents

(continued)

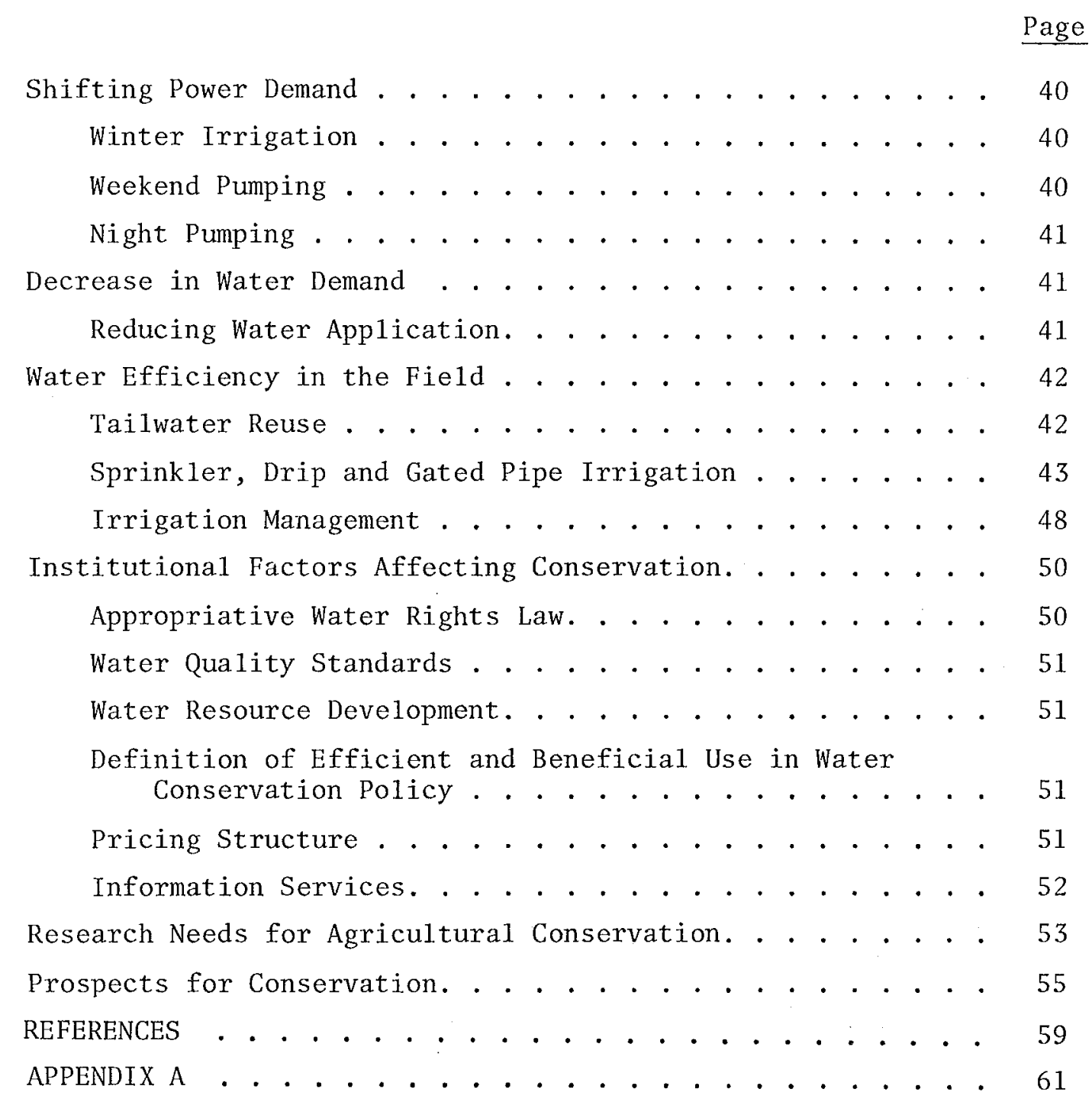


List of Tables

Table Page

1 California Precipitation. . . . . . . . . . . . . . . . 4

2 Estimated Water Supply and Demand in the Central Valley $(1976-78)$. . . . . . . . . . . . . . . . . 5

3 Estimated Agricultural Water Supply and Demand in the Central Valley-1977... . . . . . . . . . . . 10

4 Estimated Groundwater We11 Depth in the Central Valley. . . 10

5 Energy Use Per Acre-Foot in the Central Valley. . . . . . . 10

6 Water Requirements per Acre in the Central Valley . . . . . 12

7 Energy Use per Acre for Crops in the Centra1 Valley . . . . 14

8 Estimated Major Crop Acreage in the Central Valley-1977 . . 15

9 Percentage of Acreage in Surface and Sprinkler Systems in the Central Valley (1972) . . . . . . . . . . . . . 17

10 Total Energy Use for Selected Crops in the Central Valley by Water Source and Irrigation Method . . . . . . . . . . 18

11 Total Estimated Energy Requirements for Agricultural Irrigation in Central Valley-1977 . . . . . . . . . . . . . 19

12. Monthly Electricity Sales to Agriculture (1975-77) . . . . 21

13 Plantings of Selected Crops in California (1975-77) . . . . 27

14 Irrigation Pumping Energy for Selected Hydrologic Basins. . 32

151976 Pump Lift and Efficiency Tests . . . . . . . . . . . 32

16 Strategies of Agricultural Electricity Conservation . . . . 34

17 Energy Required to Lift One Acre-Foot Water One Foot. . . . 37

18 Number of Pumping Plants at a Level of Performance by Age . 39

19 Number of Pumping Plants Attaining a Level of Performance with Various Pumping Lifts . . . . . . . . . . . . . 39

20 Pumping Energy Requirements for Different Irrigation Methods Using Groundwater . . . . . . . . . . . . . . . . 44

21 Cost Factors of Irrigation Systems . . . . . . . . . . . . 47

22 Irrigation Management Service . . . . . . . . . . . . . 59 
$-v i \mathbf{i -}$

\section{List of Figures}

Figure

Page

1 California Water System . . . . . . . . . . . 3

2 Hydrologic Basin Planning Areas . . . . . . . . . . 8

3 Electricity Sales to Agriculture (1975-77) (P G \& E). . . . 22

4 Comparison of Energy Demands for Different Irrigation Methods . . . . . . . . . . . . . . . . 42 
-viii-

\author{
Energy \& Water Use in Irrigated Agriculture \\ During Drought Conditions
}

SUMMARY

Approximately 9 million acres harvested in California during 1977 were irrigated. Electrical energy is an essential input to this form of agriculture. Over 90 percent of the irrigation pumping units in the state are electrical. A higher than normal demand from the agricultural sector for electric power can result from pumping ground water in areas where the surface water supp1y has fallen below norman as a result of drought conditions.

The objectives of the study are to:

1) determine water and energy use for agricultural irrigation during the 1977 season;

2) describe the responses of agriculture to the drought conditions of 1977 and;

3) identify the present and potential water and energy conservation strategies applicable to California.

The methodology used for determining electricity requirements to pump irrigation water focused on the hydrologic basins of the Central Valley. The method employed the following facotrs: unit energy use to obtain surface and ground water, average water use by individual crops, type of irrigation, and estimated crop acreage planted in 1977. The total energy requirements for pumping in the Central Valley were estimated to be 5.91 billion Kwh, which was slightly higher than the total yearly electrical sales to agriculture reported by $\mathrm{PG} E \mathrm{E}$.

Growers used several energy and water conservation strategies in response to the drought conditions of 1976 and 1977. The strategies included an increase use of ground water, increased efficiency of water application, reduced application of water, and shifts in cropping patterns. Drought-related losses to irrigated agriculture were minimized as a result of these modifications. 
Some future problems may have been created, however, by obtaining the needed water supplies for 1976-77. These problems include the effects of extensive water pumping on ground water reservoirs and ground subsidence. Furthermore, reduced water application by less frequent irrigation and changes in irrigation methods may affect the total salt balance picture for future years.

Several conservation strategies that have some potential application in California were identified. Among the general approaches are: maintaining and augmenting surface water supply, decreasing electrical demand by use of alternative sources of energy, shifting power demand away from peak periods, increasing pump and well efficiencies and increasing water efficiency in the field. Electricity savings associated with water conservation have been estimated as high as 25 percent.

In the agricultural sector, conserving water and energy are complexly inter-related. The treatment of conservation in this paper emphasized strategies that could be implemented in the near term. Specific actions suggested for facilitating conservation included: an expanded irrigation management system; efficient water delivers at the irrigation district level and a continued effort on the part of the individual growers to use resources during periods of normal rainfall as they were used under drought conditions. 
INTRODUCTION

Energy requirements for irrigation vary widely across California as a function of the proximity of water sources, the methods of irrigation and the water requirements of the crops. The objectives of this study are to:

1) determine water and energy use for agricultural irrigation and during the 1977 season;

2) describe the responses of agriculture to the drought conditions of 1977; and,

3) identify the present and potential water and energy conservation strategies applicable to California.

The analysis of electricity and water requirements for irrigated agriculture was started as a part of a two-phase project conducted by Lawrence Berkeley Laboratory in cooperation with the San Francisco Operations Office of the Department of Energy. ${ }^{1,2}$ The purposes of that overall study were to assess the impacts of the drought on California electricity supply and demand, to evaluate remedial measures, and to develop a methodology for such assessments.

The methodology used for determining electricity requirements to pump irrigation water focused on the hydrologic basins of the Central Valley. The method employed several factors to calculate the final energy demand for pumping. The factors included unit energy use to obtain ground and surface water, average water use by individual crop, type of irrigation and estimated crop acreage planted in 1977. Section II ("Energy/Water Use During Drought Year") contains the assumptions and calculations used to determine the total electricity demand.

The dry years of 1976 and 1977 present an opportunity to gain a better understanding of how farmers meet their irrigation needs with limited supplies of surface water. Section III ("Agriculture's Responses of prought Conditions") outlines the major strategies employed in 1977. Since the overall purpose of this present study is to determine if this information can help develop a long-term approach for water and energy conservation in irrigated agriculture, the present and potential conservation strategies applicable to California were identified and presented in Section IV. 
ENERGY/WATER USE DURING A DROUGHT YEAR (1977)

Water Supply \& Demand in 1977

California's agricultural industry has experienced a second year of drought conditions north of the Tehachapi Mountains. Water shortages during 1977 have been of only minor concern in southern Califormia and most central coast areas, but are particularly troublesome and costly in the Central Valley.

A map of California shown in Figure 1 depicts the varying effects of the drought by area. Table 1 contains a comparison of the average precipitation in various areas of the state between a normal year and the 1976-77 water year. As demonstrated by the map and the corresponding table, the central coast counties and those of the coastal and desert regions of southern California received precipitation that was close to norma1. Furthermore, sufficient surface water was available in the southern California area from the Colorado River to eliminate any drought threat to this agricultural region. Other areas of the state, namely the North Coast, San Francisco Bay, Mountain, and Central Valley (Sacramento and San Joaquin Va1leys) did not fare as we11.

Although contributing only about three percent directly to the value of agricultural production in California, the Mountain area supplies most of the surface water used by the Sacramento and San Joaquin Valleys. This water is usually stored in reservoirs located in that area. In the 1976-77 water year, however, these areas generally have received the lowest percentage of the state's precipitation. As of July 1977, reservoir storage in the state was about 37 percent of normal on the average. 3

The major suppliers of surface water for irrigation in the Sacramento and San Joaquin Valleys are the federal Central Valley Project (CVP) and the State Water Project (SWP). During 1977, the CVP announced cutbacks of 75 percent to agxicultural users while the SWP reported cutbacks of 60 percent. ${ }^{3}$ If the same amount of ground water had been pumped as in a normal year, the Sacramento Valley would have received about 25 percent less total water supplies and the San Joaquin Valley 20 percent less than 1976. Table 2 summarizes the estimated water supply and demands in the Central Valley for 1976 and 1977. Table 3 disaggregates the 1977 values by hydrologic basins. 


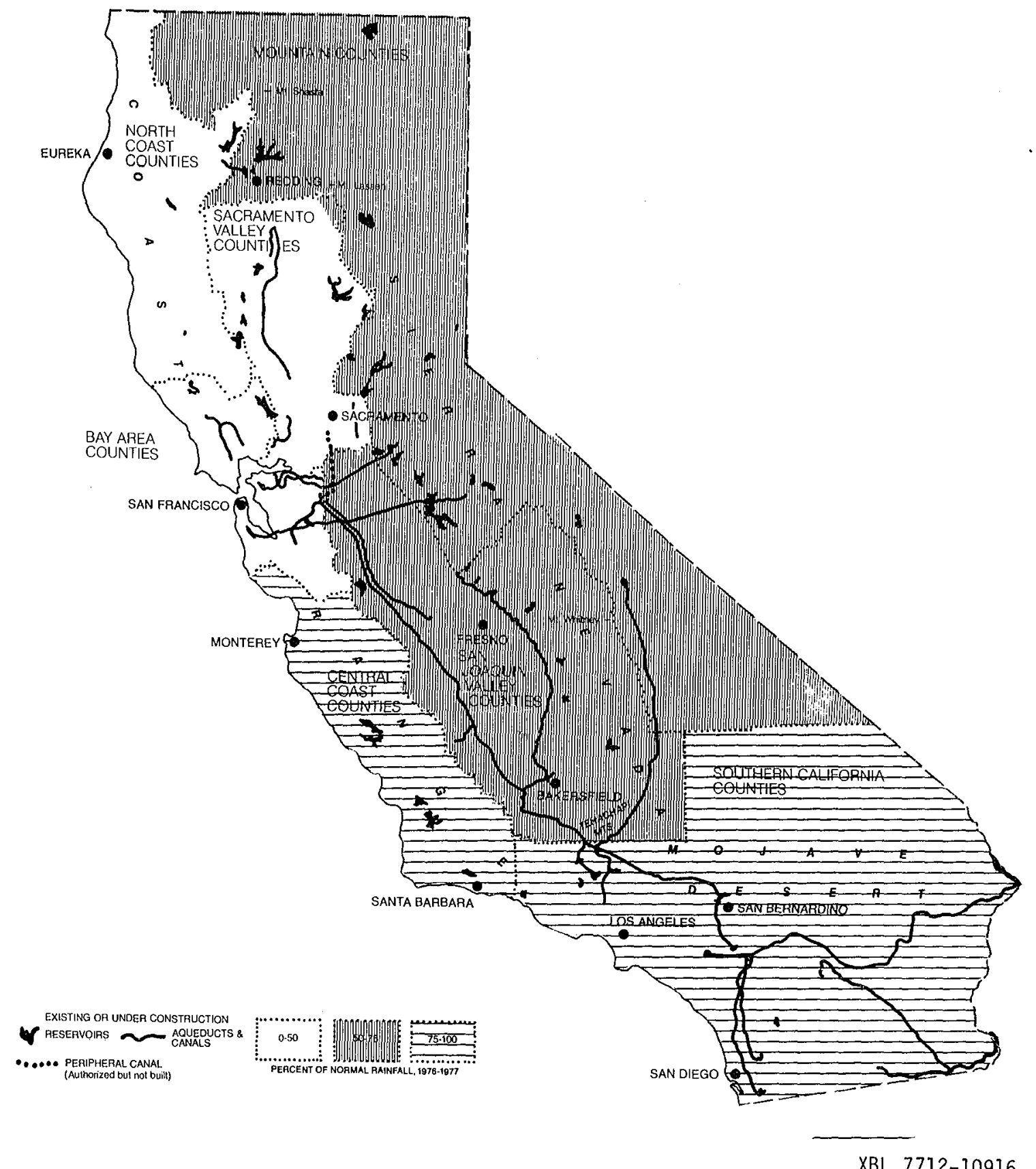

XBL 7712-10916

Figure 1. Ca1ifornia Water System 
Table 1

California Precipitation ${ }^{\mathrm{a}}$

\begin{tabular}{lccc}
\hline \multicolumn{1}{c}{ Areas } & $\begin{array}{c}\text { Normal } \\
\text { Year } \\
\text { (inches) }\end{array}$ & $\begin{array}{c}\text { Percent of } \\
\text { Norma1 } \\
\text { (July 1974- } \\
\text { June 1975) }\end{array}$ & $\begin{array}{c}\text { Percent of } \\
\text { Norma1 } \\
\text { (July 1976- } \\
\text { June 1977) }\end{array}$ \\
\hline North Coast & 37.6 & 105 & 42 \\
San Francisco Bay & 21.6 & 96 & 47 \\
Central Coast & 12.6 & 96 & 88 \\
Sacramento Valley & 20.4 & 100 & 68 \\
San Joaquin Valley & 9.5 & 91 & 94 \\
Southern California & 7.9 & 57 & 58 \\
Mountain & 32.4 & 94 & \\
\hline
\end{tabular}

average precipitation at weather stations in each area as reported by California Crop and Livestock Reporting Service, USDA (July-June weather year).

${ }^{b}$ Average of coastal and desert stations. 
Table 2

Estimated Water Supply and Demand in the Centra1 Valley (1976-78) $(106 \text { acre-feet })^{a}$

\begin{tabular}{|c|c|c|c|}
\hline & $\begin{array}{c}\text { Sacramento } \\
\text { Valley }\end{array}$ & $\begin{array}{c}\text { San Joaquin } \\
\text { Valley }\end{array}$ & $\begin{array}{r}\text { Valley } \\
\text { Total }\end{array}$ \\
\hline \multicolumn{4}{|l|}{1976 Demand $\mathrm{b}$} \\
\hline $\begin{array}{l}\text { Urban } \\
\text { Agriculture } \\
\text { Total }\end{array}$ & $\begin{array}{l}1.0 \\
\frac{7.5}{8.5}\end{array}$ & $\begin{array}{r}0.7 \\
19.2 \\
19.9\end{array}$ & $\begin{array}{r}1.7 \\
26.7 \\
28.4\end{array}$ \\
\hline \multicolumn{4}{|l|}{1976 Supp $1 y^{b}$} \\
\hline $\begin{array}{l}\text { Surface } \\
\text { Ground } \\
\text { Total }\end{array}$ & $\begin{array}{l}6.5 \\
1.9 \\
8.4\end{array}$ & $\begin{array}{r}9.6 \\
10.2 \\
19.8\end{array}$ & $\begin{array}{l}16.1 \\
12.1 \\
28.2\end{array}$ \\
\hline \multicolumn{4}{|l|}{1977 Demand $^{b}$} \\
\hline $\begin{array}{l}\text { Urban } \\
\text { Agriculture } \\
\text { Tota1 }\end{array}$ & $\begin{array}{l}1.0 \\
8.0 \\
9.0\end{array}$ & $\begin{array}{r}0.7 \\
20.0 \\
20.7\end{array}$ & $\begin{array}{r}1.7 \\
28.0 \\
29.7\end{array}$ \\
\hline \multicolumn{4}{|l|}{1977 Supply } \\
\hline $\begin{array}{l}\text { Surface } \\
\text { Ground } \\
\text { Tota1 }\end{array}$ & $\begin{array}{l}4.6 \\
2.5 \\
7.1\end{array}$ & $\begin{array}{r}4.8 \\
12.2 \\
17.0\end{array}$ & $\begin{array}{r}9.4 \\
14.7 \\
24.1\end{array}$ \\
\hline 1977 Deficit & -1.9 & -3.7 & -5.6 \\
\hline \multicolumn{4}{|c|}{ Estimated 1978 Supp1y } \\
\hline $\begin{array}{l}\text { Surface } \\
\text { Ground } \\
\text { Total }\end{array}$ & $\begin{array}{l}3.9 \\
2.5 \\
6.4\end{array}$ & $\begin{array}{r}3.2 \\
12.2 \\
15.4\end{array}$ & $\begin{array}{r}7.1 \\
14.7 \\
21.8\end{array}$ \\
\hline 1978 Deficit & -2.6 & -5.3 & -7.9 \\
\hline
\end{tabular}

$\mathrm{a}_{\text {An }}$ acre-foot $=325,851$ ga11ons .

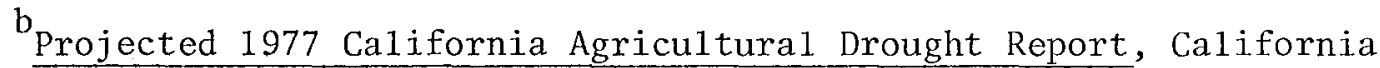
Department of Food and Agriculture, August 1977 (ref. 4).

$\mathrm{c}_{\text {The Continuing California Drought, California Department of Water }}$ Resources, August 1977 (ref. 3). Assumes 1977 surface runoff in 1978 and same groundwater pumping as 1977. 
Surface water supplies in the Central Valley were down over 40 percent in 1977 from the 1976 level. Ground water pumping increased by over 20 percent to compensate for this deficiency with an estimated 7,500 new we11s drilled in California during 1977.4 In addition to dri11ing new we11s, farmers reactivated dormant wells in large numbers in the Central Valley. By the end of 1977, ground water accounted for at least 53 percent of a11 water used by agriculture in California, compared with a norma1 year average of 40 percent. ${ }^{4}$ Even with the increase in ground water pumping during 1977 in the Central Valley, there was a total deficit between estimated water supply and demand of 5.6 million acre-feet.

During drought periods the state's most significant source of reserve supply is ground water. In a normal year ground water pumping in the state accounts for about 15 million acre-feet. 5 It is estimated that 50 percent of this water results from the recharge percolation of applied surface water, 36 percent is due to natural recharge, and the remainder is overdrafted from ground water storage basins. ${ }^{3}$ In 1976 with less applied surface water there was a reduction in deep percolation to recharge ground water reservoirs and subsequently an increase in the amount of water removed from storage. The quantity of ground water overdraft in 1976 was estimated to be 4.9 million acre-feet compared to about 2.1 million acre-feet in 1975 . Over 80 percent of this overdraft occurred in the Central Val1ey with the worst impact in the southern San Joaquin Va11ey. In 1977, because of a continued reduction in surface water supply, pumping from ground water storage reservoirs may reach as much as 10 million acre-feet out of the statewide total of 18.5 million acre-feet. $^{3}$ The major portion of this overdraft ( 8 million acre-feet) will occur in the Central Valley.

With the increased pumping in the Sacramento and San Joaquin Valleys the water table is expected to drop even more than the 1976 record. In the northern Sacramento Valley, the average ground water levels in 1977 were 3.6 feet lower than in 1976. This decline is in addition to the average lowering of 6 feet in the previous year of the drought. In the lower Sacramento Valley where ground wells are the major source for water, the levels have fallen between 5 and 10 feet from the levels of $1976 .{ }^{3}$ 
In the San Joaquin Valley, the effect of increased ground water pumping during 1976 is represented by the lowering of water table leve1s along the eastern sides of the Valley. Comparison of 1977 levels to those reported in 1976 indicate an average drop between 5 and 13 feet. ${ }^{3}$ Ground water leve1s for the western portion of the San Joaquin Valley, which rely minimally on ground water supplies, continued to rise or remain stable.

Declines in the ground water table result in additional energy requirements for pumping at the greater depths. Assuming a pump efficiency of 55.5 percent, each additional foot of pumping requires about 1.85 kilowatt-hours per acre-foot of water pumped. The farmer is thus faced with the cost for drilling a new well which ranges from $\$ 30,000$ to $\$ 150,000$ depending on the size and depth.

In addition to the expense of drilling a new we11 or reactivating an abandoned one, there are the increased energy costs. The average cost to pump an acre-foot of water ranges from $\$ 33$ to $\$ 40$ from a we11, compared to a price of $\$ 8.50$ to $\$ 11$ for surface water from a canal. ${ }^{4}$ During 1977 some water districts (e.g., Westlands Water District) purchased northern California water normally used for rice irrigation at a cost of about $\$ 68$ per acrefoot. This water was made available as needed for the survival of trees and vines. In water districts in which the water is delivered (e.g., wheeler Ridge-Maricopa Water Storage District), the costs have increased from $\$ 44$ per acre-foot to nearly $\$ 123$ per acre-foot.

Energy Requirements For Agricultural Water Demands

The Sacramento and San Joaquin Valleys, which comprise the Centra1 Valley, account for nearly 60 percent of the state's cash receipts from farm marketing of crops. Since nearly 80 percent of the estimated water use in agriculture and 75 percent of the energy requirements for pumping occur in four of the 16 hydrologic basins (5A, 5B, 5C, 5D) established by the State Water Resources Control Board (Fig. 2), these basins were used as the basic geographic area for all energy calculations. Furthermore, the major part of the area represented by these basins lies within the Pacific Gas and Electric Company's (PGGE) service area. A part of the Tulare Basin (50) is serviced by Southern California Edison Company (SCE) . 


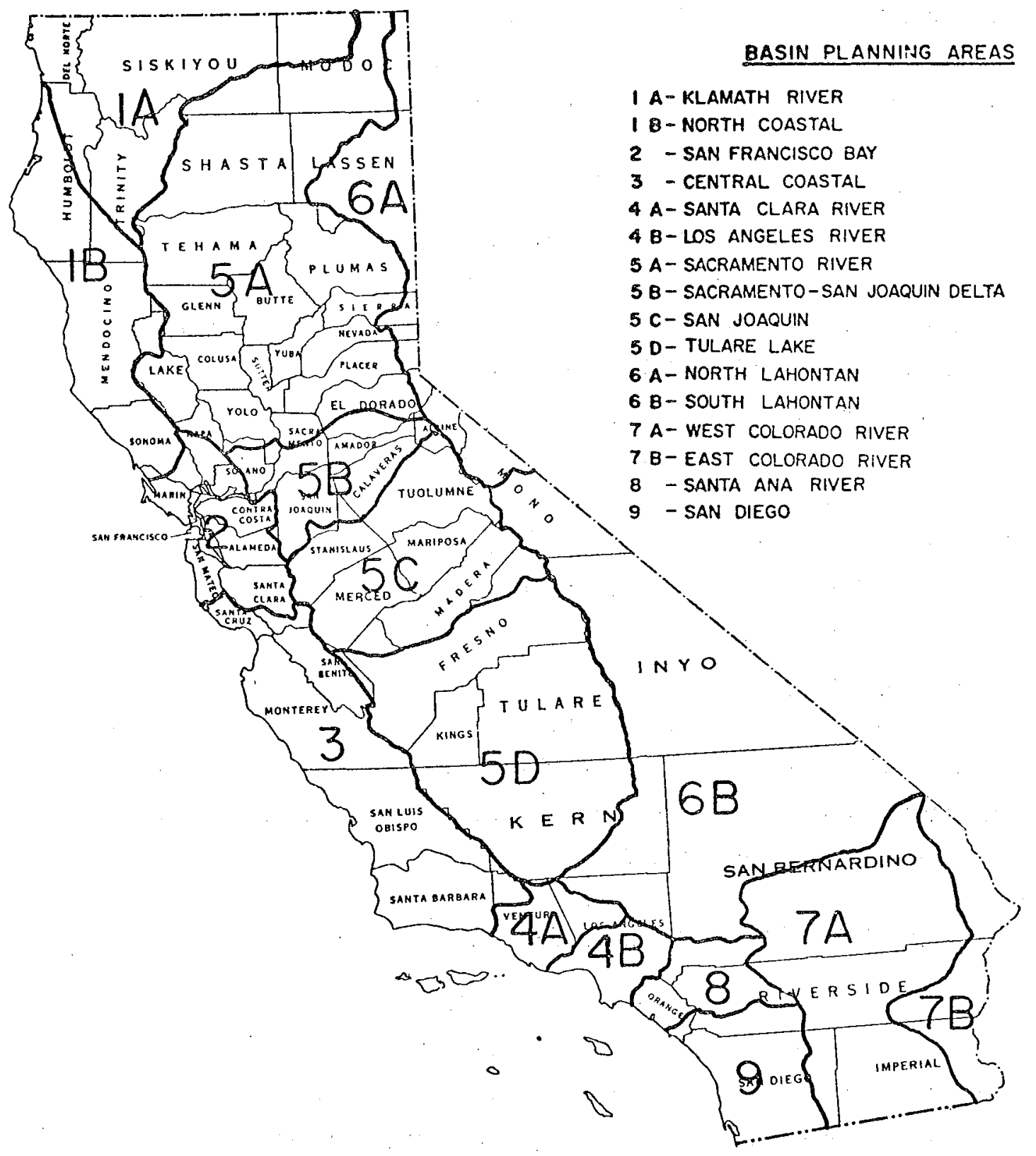

XBL 776-8970

Figure 2. Hydrologic Basin Planning Areas 
This section estimates energy use by crop and irrigation method in the four hydrologic basin planning areas of the Central Valley. The basic approach used to determine energy requirements for agricultural pumpirg in the Central valley follows the procedure used in a recent report. 6 Energy requirements are calculated for 1) on-farm we11s incorporating the best available data on average well depths in the Central Valley; 2) pumping energy required for moving water within the state and federal water projects; 3) energy required by irrigation districts for pumping water. The latter two energy values are taken from recently published and unpublished reports (Refs. 6 and 7). The energy calculations are based on average values within each hydrologic basin for factors such as well depths, water requirements, planted acreage, and irrigation systems.

Unit Energy Use for Ground and Surface Water

In order to calculate the energy requirements for ground water the average pumping depth for wells in each hydrologic planning basin was estimated. Average pumping depths were taken from the estimates for 1972 by determining the average static water level for each basin and adding the average draw down (21 feet) and average surface irrigation pressure head (4 feet). Since the water table has been generally declining throughout the state, it was necessary to update the data presented by Knutson. 6 Information on the average drop in groundwater levels was obtained from the various districts of DWR which represent the Centra1 Valley. The estimated ground water well depths are presented in Table 4. These values, which are basin averages, are used to determine the energy required to pump ground water to the surface.

An average overa11 pumping plant efficiency of 55 percent was used. This value is a weighted average obtained from measurements reported to USBR. $^{12}$ Although this is a more conservative figure than the percentage used in other studies, ${ }^{6,9}$ it is probably more representative of the overa 1 picture in the Central Valley. By combining the average pumping efficiency with the pumping depth, the energy used to pump ground water was determiner by the following formula:

$$
\text { Unit Energy Use }(\mathrm{Kwh} / \mathrm{AF})=1.024 \times \quad \frac{\mathrm{D}}{\mathrm{E}}
$$


Tab1e 3

Estimated Agricultural Water

Supply and Demand in the Centra1 Valley - 1977 $\left(10^{6} \text { acre-feet }\right)^{a}$

\begin{tabular}{lccccr}
\multicolumn{1}{c}{ Water Source } & $5 \mathrm{~A}$ & $5 \mathrm{~B}$ & $5 \mathrm{C}$ & $5 \mathrm{D}$ & $\begin{array}{r}\text { Valley } \\
\text { Totals }\end{array}$ \\
\hline Surface Water & 4.01 & 1.56 & 2.06 & 1.71 & 9.34 \\
Groundwater & $\underline{2.43}$ & $\underline{1.12}$ & $\underline{2.73}$ & $\underline{8.46}$ & $\underline{14.74}$ \\
TOTAL WATER SUPPLY $^{\mathrm{b}}$ & 6.44 & 2.68 & 4.79 & 10.16 & 24.08 \\
Percent Surface Water & 62.3 & 58.3 & 43.0 & 16.7 & \\
Percent Groundwater & 37.7 & 41.7 & 57.0 & 83.2 & \\
WATER DEMAND $^{\text {C }}$ & 8.30 & 2.56 & 6.71 & 12.13 & 29.70 \\
\hline
\end{tabular}

$\mathrm{a}_{\text {An }}$ acre-foot $=325,851$ gallons.

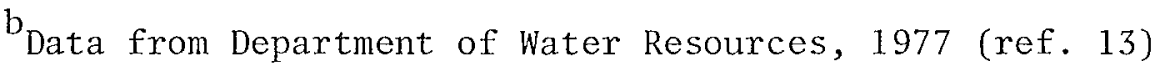

$\mathrm{c}_{\text {Estimated total applied water demand }}$

Table 4

Estimated Groundwater Well Depth in the Central Valley

\begin{tabular}{cccc}
\hline $\begin{array}{c}\text { Hydrologic } \\
\text { Planning } \\
\text { Basin }\end{array}$ & $\begin{array}{c}\text { Pumping Depth } \\
\text { (feet) } \\
1972 \text { Data }\end{array}$ & $\begin{array}{c}\text { Average Drop in } \\
\text { Groundwater Leve1 } \\
(1972-77)\end{array}$ feet $^{b}$ & $\begin{array}{c}\text { Estimated Pumping } \\
\text { Depth in 1977 } \\
\text { (feet) }\end{array}$ \\
\hline 5A & 53 & 8 & 61 \\
5B & 89 & 8 & 97 \\
5C & 123 & 4 & 127 \\
$5 D$ & 181 & 7 & 188 \\
\hline
\end{tabular}

$a_{\text {Knutson, et a1., } 1977 \text { (ref. 6) }}$

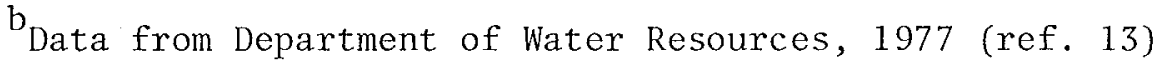

Tab1e 5

Energy Use Per Acre-Foot in the Centra 1 Valley $(\mathrm{kWh} / \mathrm{AF})^{\mathrm{a}}$

\begin{tabular}{lrrrr}
\hline \multicolumn{1}{c}{ Irrigation Method } & $5 \mathrm{~A}$ & $5 \mathrm{~B}$ & $5 \mathrm{C}$ & $5 \mathrm{D}$ \\
\hline $\begin{array}{l}\text { Surface Irrigation From: } \\
\quad \text { Groundwater }\end{array}$ & 113 & 180 & 236 & 350 \\
$\quad$ Surface Water & 18 & 43 & 204 & 258 \\
Sprinkler Irrigation From: & & & & \\
$\quad$ Groundwater & 347 & 414 & 470 & 584 \\
$\quad$ Surface Water & 252 & 277 & 438 & 492 \\
\hline
\end{tabular}

Assumes $55 \%$ pumping efficiency. 
where: $\quad K w h / A F=K i l o w a t t-h o u r$ per acre-foot

$1.024=$ number of kilowatt-hours to 1 ift one acre-foot of water one foot in height at 100 percent efficiency

D $\quad=$ pumping depth (feet)

$\mathrm{E} \quad=$ overall pumping plant efficiency (55 percent)

Table 5 presents the energy required to pump ground water in the Central Valley. The ground water numbers were calculated according to Eq. 1. The surface water numbers represent the average energy per acre-foot required for moving irrigation water by state and federal water projects and pumping water by irrigation districts. They were determined in recent studies. 7,8,9 Sprinkler irrigation requires energy equivalent to an additional 126 foot lift.

Unit Water Use by Crop

Data in Table 6 on the expected water requirements for various crops within each Central Valley hydrologic basin were taken from three reports. 6,10,11 These average values for the amount of water applied per acre were given in Knutson's paper for different methods of application. Comparisons were made between surface and sprinkler methods which are used on the majority of the irrigated acreage in California.

The amount of water applied per acre is affected by the average application efficiency of the different methods of irrigation. Since little data are available on the relative application efficiencies of the different irrigation methods, average water application efficiencies of 65 percent for surface irrigation and 81 percent for sprinklers were used. These figures are based on current practice. The details of the calculations which were computed on an acre weighted basis are given in another report. ${ }^{6}$

Unit Energy Use by Crop

The energy use per acre for various crops in the Central Valley was calculated by a method used previously. ${ }^{6}$ The procedure consisted of combining the energy required to pump one acre-foot of water (Kwh/AF) from either surface or ground water sources with the water used per acre of crop (AF/acre). The following formula were used; 
Table 6

Water Requirements per Acre in the Central Valley* (Acre-foot/Acre)

\begin{tabular}{|c|c|c|c|c|c|c|c|c|c|c|}
\hline $\mathrm{HBPA}^{* *}$ & $\begin{array}{l}\text { Irrigation } \\
\text { Method } \\
\end{array}$ & Alfalfa & Corn & Cotton & Grain & Rice & $\begin{array}{l}\text { Sugar } \\
\text { Beets } \\
\end{array}$ & $\begin{array}{c}\text { Fruit/ } \\
\text { Nuts }\end{array}$ & Vines & $\begin{array}{l}\text { Vege- } \\
\text { tables }\end{array}$ \\
\hline $5 \mathrm{~A}$ & Surface & 3.9 & 2.5 & -- & 1.0 & 8.2 & 3.1 & 3.2 & 3.0 & 2.7 \\
\hline $5 \mathrm{~A}$ & Sprinkler & 3.1 & -- & -- & 0.8 & -- & 2.5 & 2.5 & 2.4 & 2.2 \\
\hline $5 B$ & Surface & 3.5 & 2.2 & -- & 1.0 & 8.2 & 3.0 & 3.2 & 2.5 & 2.7 \\
\hline $5 \mathrm{~B}$ & Sprinkler & 2.8 & -- & -- & 0.8 & -- & 2.4 & 2.5 & 2.0 & 2.3 \\
\hline $5 \mathrm{C}$ & Surface & 5.2 & 3.2 & 4.0 & 1.0 & 6.7 & 3.7 & 4.1 & 3.6 & 2.3 \\
\hline $5 \mathrm{C}$ & Sprinkler & 4.1 & -- & 3.2 & 0.8 & -- & 2.9 & 3.2 & 2.8 & 1.8 \\
\hline $5 \mathrm{D}$ & Surface & 5.6 & 3.4 & 4.2 & 1.2 & 6.7 & 3.8 & 4.0 & 4.0 & 2.2 \\
\hline $5 \mathrm{D}$ & Sprinkler & 4.5 & -- & 3.3 & 1.0 & -- & 3.0 & 3.2 & 3.2 & 1.8 \\
\hline VALLEY & AVERAGE & 4.5 & 2.8 & 3.9 & 1.1 & 7.5 & 3.3 & 3.5 & 3.2 & 2.3 \\
\hline
\end{tabular}

*Knutson, et al., 1977 (Ref. 6).

** Hydrologic Basin Planning Areas 
Surface Irrigation: (kWh/AF) X (AF/Acre) for each crop Sprinkler Irrigation: $\left[\begin{array}{ll}(\mathrm{kWh} / \mathrm{AF})+ & \text { additional energy } \\ \text { for sprinkler } \\ \text { pressure head }\end{array}\right] \times$ (AF/Acre) for each crop

The energy use per acre of crop (kWh/Acre) for the hydrologic basins of the Central Valley is tabulated in Table 7. Energy requirements are presented for both surface and sprinkler irrigation methods using either ground or surface water.

\section{Estimated Crop Acreage in the Central Valley}

In order to complete an energy analysis of agricultural pumping it was necessary to estimate the acreage planted for each crop in the various hydrologic basins of the valley. This task proved to be the most difficult because of a lack of definitive data on expected cropping patterns for the 1977 growing season.

The procedure used the June 1977 report on farmers' intentions to plant various crops in California. ${ }^{16}$ This information was available on a statewide basis. Information obtained through various conversations with the staff members of the State Department of Food and Agriculture was used to separate the Central Valley crop intentions from the state totals. Finally the estimated planted acreages were apportioned to the hydrologic basins according to historical cropping patterns. ${ }^{6,11}$ Since the data in these studies on planted acreage pertained to the year 1972, a comparison was made to 1975-76 information on production and yield. The percentages of total statewide acreage estimated in each hydrologic basin within the Central Valley did not change significantly during this time period, and so 1972 data on the percentage of each crop planted in the four hydrologic planning basins were used to estimate 1977 acreage.

The estimated planted acreage in the Central Valley by crop for 1977 is presented in Table 8. These crop estimates are apportioned to the appropriate hydrologic basin by the method described above. It is important to note that the figures are only approximations and may differ significantly from actual plantings. 
Table 7

Energy Use per Acre for Crops in the Central Valley (kwh/acre)

\begin{tabular}{|c|c|c|c|c|c|c|c|c|c|c|}
\hline $\mathrm{HPBA}^{*}$ & $\begin{array}{l}\text { Irrigation Method/ } \\
\text { Water Source } \\
\end{array}$ & Alfalfa & Corn & Cotton & Grain & Rice & $\begin{array}{l}\text { Sugar } \\
\text { Beets }\end{array}$ & $\begin{array}{l}\text { Fruit/ } \\
\text { Nuts } \\
\end{array}$ & Vines & Vegetables \\
\hline \multirow[t]{3}{*}{$5 \mathrm{~A}$} & Surface Irrigation & & & & & & & & & \\
\hline & Groundwater & 441 & 283 & - & 113 & 927 & 350 & 362 & 339 & 305 \\
\hline & Surface water & 70 & 45 & -- & 18 & 148 & 56 & 58 & 54 & 49 \\
\hline \multirow[t]{3}{*}{$5 \mathrm{~A}$} & Sprinkler Irrigation & & & & & & & & & \\
\hline & Groundwater & 1076 & -- & -- & 278 & -- & 868 & 868 & 833 & 763 \\
\hline & Surface water & 781 & -- & -- & 202 & -- & 630 & 630 & 605 & 554 \\
\hline \multirow[t]{3}{*}{$5 B$} & Surface Irrigation & & & & & & & & & \\
\hline & Groundwater & 630 & 396 & -- & 180 & 1476 & 540 & 576 & 450 & 486 \\
\hline & Surface water & 151 & 95 & -- & 43 & 353 & 129 & 138 & 108 & 116 \\
\hline \multirow[t]{3}{*}{$5 B$} & Sprinkler Irrigation & & & & & & & & & \\
\hline & Groundwater & 1159 & -- & -- & 331 & -- & 994 & 1035 & 828 & 952 \\
\hline & Surface water & 776 & -- & - & 222 & -- & 665 & 693 & 554 & 637 \\
\hline \multirow[t]{3}{*}{$5 \mathrm{C}$} & Surface Irrigation & & & & & & & & & \\
\hline & Groundwater & 1227 & 755 & 944 & 236 & 1581 & 873 & 968 & 850 & $5 \nmid 3$ \\
\hline & Surface water & 1061 & 653 & 816 & 204 & 1367 & 755 & 836 & 734 & 469 \\
\hline \multirow[t]{3}{*}{$5 \mathrm{C}$} & Sprinkler Irrigation & & & & & & & & & \\
\hline & Groundwater & 1927 & -- & 1504 & 376 & -- & 1363 & 1504 & 1316 & 846 \\
\hline & Surface water & 1796 & -- & 1402 & 350 & -- & 1270 & 1402 & 1226 & 788 \\
\hline \multirow[t]{3}{*}{$5 D$} & Surface Irrigation & & & & & & & & & \\
\hline & Groundwater & 1960 & 1190 & 1470 & 420 & 2345 & 1330 & 1400 & 1400 & 770 \\
\hline & Surface water & 1445 & 877 & 1084 & 310 & 1729 & 980 & 1032 & 1032 & 568 \\
\hline \multirow[t]{3}{*}{$5 D$} & Sprinkler Irrigation & & & & & & & & & \\
\hline & Groundwater & 2628 & -- & 1927 & 584 & -- & 1752 & 1869 & 1869 & 1051 \\
\hline & Surface water & 2214 & -- & 1624 & 492 & -- & 1476 & 15.74 & 1574 & 886 \\
\hline
\end{tabular}

*Hydrologic Planning Basin Areas 
Table 8

Estimated Major Crop Acreage in the Central Valley - 1977

\begin{tabular}{|c|c|c|c|c|c|c|c|c|c|}
\hline \multirow{2}{*}{ CROPS } & \multirow[b]{2}{*}{$\begin{array}{l}\text { Estimated } \\
\text { Statewide } \\
\text { Acreage } \\
\left(10^{3} \mathrm{~A}\right) \\
\end{array}$} & \multicolumn{2}{|c|}{$5 \mathrm{~A}$} & \multicolumn{2}{|c|}{$5 B$} & \multicolumn{2}{|c|}{$5 \mathrm{C}$} & \multicolumn{2}{|c|}{$5 D$} \\
\hline & & $\begin{array}{l}\% \text { State } \\
\text { Acreage }\end{array}$ & $\begin{array}{l}\text { Estimated } \\
\text { Acres }-1977 \\
\left(10^{3} \mathrm{~A}\right)\end{array}$ & $\begin{array}{l}\% \text { State } \\
\text { Acreage }\end{array}$ & $\begin{array}{l}\text { Estimated } \\
\text { Acres }-1977 \\
\left(10^{3} \mathrm{~A}\right)\end{array}$ & $\begin{array}{l}\% \text { State } \\
\text { Acreage }\end{array}$ & $\begin{array}{l}\text { Estimated } \\
\text { Acres }-1977 \\
\left(10^{3} \mathrm{~A}\right)\end{array}$ & $\begin{array}{l}\% \text { State } \\
\text { Acreage }\end{array}$ & $\begin{array}{c}\text { Estimated } \\
\text { Acres }-1977 \\
\left(10^{3} \mathrm{~A}\right)\end{array}$ \\
\hline Al fal fa & 1680 & 15.2 & 255.4 & 9.8 & 164.6 & 22.6 & 379.7 & 25.4 & 426.7 \\
\hline Corn & 450 & 18.2 & 81.9 & 21.8 & 98.1 & 27.1 & 122.0 & 30.6 & 137.7 \\
\hline Cotton & 1400 & -- & -- & -- & -- & 9.1 & 127.4 & 71.9 & 1006.6 \\
\hline Grain & 1250 & 8.3 & 103.8 & 8.6 & 107.5 & 4.7 & 58.8 & 48.6 & 607.5 \\
\hline Rice & 320 & 89.2 & 285.4 & 2.1 & 6.7 & 7.4 & 23.7 & 1.4 & 3.8 \\
\hline Sugar Beets & 210 & 35.4 & 74.3 & 27.1 & 56.9 & 12.9 & 27.1 & 21.9 & 46.0 \\
\hline Fruits/Nuts & 1335 & 32.7 & 436.5 & 17.2 & 229.6 & 19.9 & 265.7 & 25.0 & 333.8 \\
\hline Vineyards & 647 & 6.7 & 43.3 & 9.1 & 58.9 & 20.0 & 129.4 & 48.1 & 311.2 \\
\hline Vegetables & 900 & 38.6 & 347.4 & 29.7 & 267.3 & 15.5 & 139.5 & 16.2 & 145.8 \\
\hline
\end{tabular}


Energy Demand for Agricultural Pumping in the Central Valley

To determine the total energy demand for agricultura1 pumping, which is the objective of this section of the report, the energy use per acre was multiplied by the estimated acreage in the Central Valley water basins. These computations were made for surface and sprinkler irrigation methods using water from either ground or surface sources.

Certain assumptions related to irrigation systems and water sources were made in order to obtain the appropriate acreages. First, it was assumed that the irrigation patterns reported previously had not changed significantly. ${ }^{6,11}$ The percentages of acreage used for surface and sprinkler irrigation systems, as shown in Table 9 were taken from the 1972 data, and were apportioned to the estimated planted acres in 1977.

The second assumption is that the proportion of acreage using surface and sprinkler systems for a given hydrologic basin applied equally to water from ground and surface sources, i.e., that ground water and surface water were used in the same ratio in sprinkler irrigation as they were in surface irrigation. Therefore the acreage employing surface and sprinkler irrigation methods was applied to the ratio of ground and surface water available within each hydrologic basin for 1977 as shown in Table 2. The results of such calculations are the estimated planted acreage by water source and irrigation method.

The estimated planted acreages were then multiplied by the appropriate energy use per acre value as presented in Table 7 to give the total energy use for the various crops in each hydrologic basin. Table 10 contains the total energy use for selected crops according to the water source and irrigation method. The data are summarized in Table 11 as the estimated total energy requirements for agricultural pumping in the Centra1 Va11ey.

The total energy requirements for agricultural pumping in the Central Valley during 1977 were calculated to be 5.91 billion kWh. This energy value is slightly greater than the total yearly electricity sales to agriculture reported by $P G$ \& E. (See Table 12.). The difference in total energy needs is due to a number of factors. We assumed an overall average pumping efficiency of 55 percent, while the actual efficiencies are probably greater. PG E E's service area covers the major portion of the Central Valley, but not 
Table 9

Percentage of Acreage in Surface and Sprinkler Systems in the Central Valley

\begin{tabular}{|c|c|c|c|c|c|c|c|c|c|c|c|c|}
\hline \multirow[b]{2}{*}{ Crops } & \multicolumn{3}{|c|}{$5 A$} & \multicolumn{3}{|c|}{$5 \mathrm{~B}$} & \multicolumn{3}{|c|}{$5 \mathrm{C}$} & \multicolumn{3}{|c|}{ 5D } \\
\hline & $\begin{array}{l}\text { Estimated } \\
\text { acres } \\
\left(10^{3} \mathrm{~A}\right) \\
\end{array}$ & $\stackrel{\%}{\text { Surface }}$ & Sprinkler & $\begin{array}{c}\text { Estimated } \\
\text { acres } \\
\left(10^{3} \mathrm{~A}\right) \\
\end{array}$ & $\stackrel{\circ}{\circ}{ }^{\circ}$ & $\stackrel{\%}{\text { Sprinkler }}$ & $\begin{array}{l}\text { Estimated } \\
\text { acres } \\
\left(10^{3} \mathrm{~A}\right) \\
\end{array}$ & $\begin{array}{c}\% \\
\text { Suxface }\end{array}$ & $\stackrel{\%}{\text { Sprinkler }}$ & $\begin{array}{c}\text { Estimated } \\
\text { acres } \\
\left(10^{3} \mathrm{~A}\right) \\
\end{array}$ & $\stackrel{\%}{\text { Surface }}$ & Sprinkler \\
\hline Alfalfa & 255.4 & 91.9 & 8.1 & 164.6 & 97.6 & 2.4 & 379.7 & 93.3 & 6.7 & 426.7 & 90.1 & 9.9 \\
\hline Corn & 81.9 & 100 & -- & 98.1 & 100 & -- & 122.0 & 100 & -- & 137.7 & 100 & -- \\
\hline Cotton & -- & -- & -- & -- & -- & -- & 127.4 & 70.0 & 30.0 & 1006.6 & 79.6 & $20: 4$ \\
\hline Grain & 103.8 & 93.2 & 6.8 & 107.5 & 99.8 & 0.2 & 58.8 & 94.7 & 5.3 & 607.5 & 95.0 & 5.0 \\
\hline Rice & 285.7 & 100 & -- & 6.7 & 100 & -- & 23.7 & 100 & -- & 3.8 & 100 & -- \\
\hline Sugar Beets & 74.3 & 80.9 & 19.1 & 56.9 & 93.6 & 6.4 & 27.1 & 92.9 & 7.1 & 46.0 & 85.7 & 14.3 \\
\hline Fruit/Nuts & 436.5 & 44.8 & 55.2 & 229.6 & 54.3 & 45.7 & 265.7 & 80.6 & 19.4 & 333.8 & 74.1 & 25.9 \\
\hline Vineyards & 43.3 & 95.0 & 5.0 & 58.9 & 95.0 & 5.0 & 129.4 & 91.5 & 8.5 & 311.2 & 93.0 & 7.0 \\
\hline Vegetables & 347.4 & 81.9 & 18.1 & 267.3 & 96.2 & 3.8 & 139.5 & 99.9 & 0.1 & 145.8 & 57.8 & 42.2 \\
\hline
\end{tabular}


Table 10

Total Energy Use for Selected Crops in the Central Valley by Water Source and Irrigation Method ${ }^{*}$

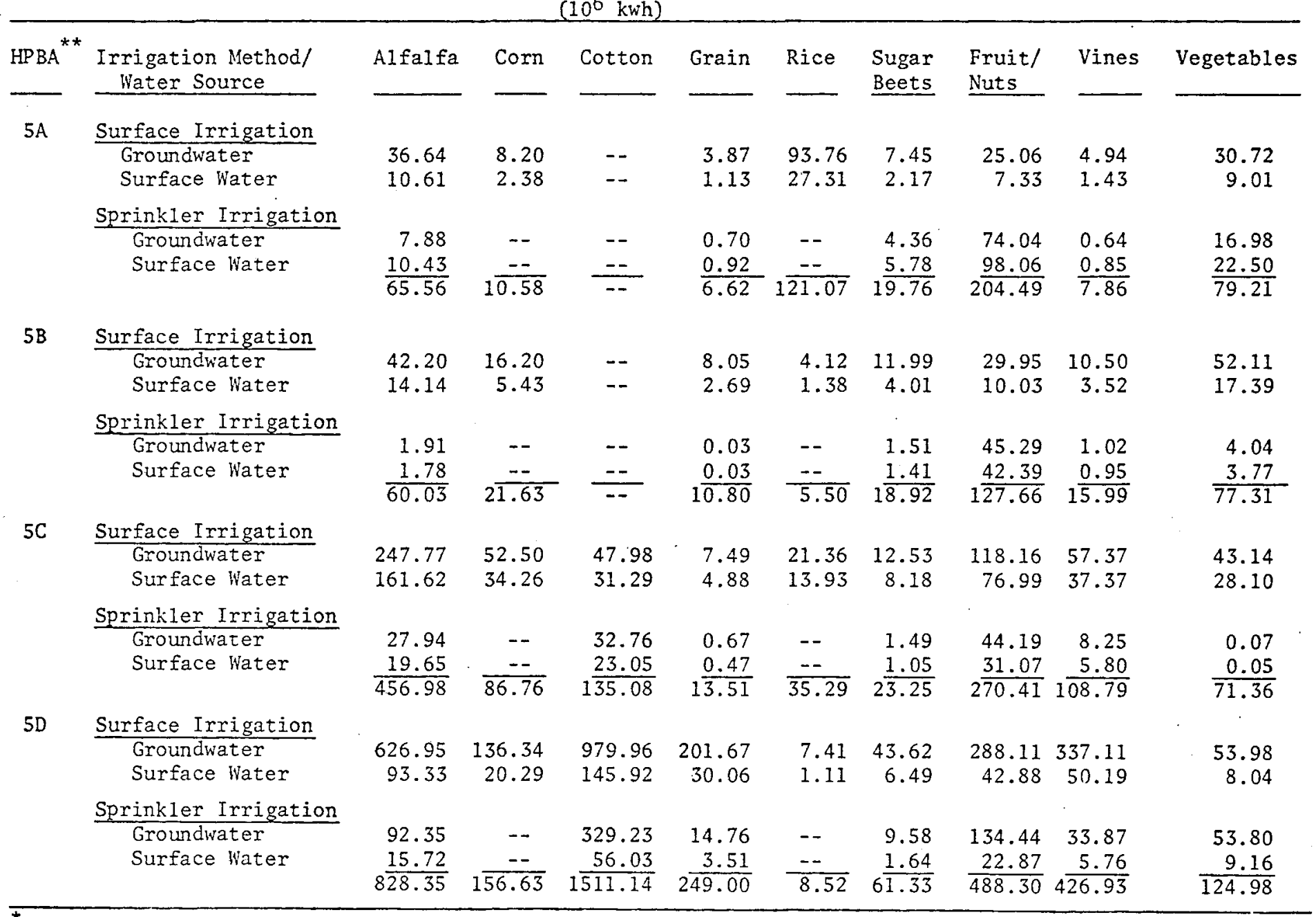

* Assumes 0.55 efficiency.

${ }^{\star \star}$ Hydrologic Planning Basin Areas 
Table 11

Total Estimated Energy Requirements for Agricultural Irrigation in Central Valley - 1977 $\left(10^{6} \mathrm{kwh}\right)$

\begin{tabular}{|c|c|c|c|c|c|c|c|c|c|c|}
\hline HPBA & Alfalfa & Corn & Cotton & Grain & Rice & $\begin{array}{l}\text { Sugar } \\
\text { Beets }\end{array}$ & $\begin{array}{l}\text { Fruit/ } \\
\text { Nuts }\end{array}$ & Vineyards & Vegetables & $\begin{array}{l}\text { Basin } \\
\text { Totals }\end{array}$ \\
\hline $5 \mathrm{~A}$ & 65.56 & 10.58 & -- & 6.62 & 121.07 & 19.76 & 204.49 & 7.86 & 74.21 & 515.15 \\
\hline $5 B$ & 60.03 & 21.63 & -- & 10.80 & 5.50 & 18.92 & 127.66 & 15.99 & 77.31 & 337.84 \\
\hline $5 \mathrm{C}$ & 456.98 & 86.76 & 135.08 & 13.51 & 35.29 & 23.25 & 270.41 & 108.74 & 71.36 & 1201.43 \\
\hline $5 \mathrm{D}$ & 828.35 & 156.63 & 1511.14 & 249.0 & 8.52 & 61.33 & 488.3 & 426.93 & 124.98 & 3855.18 \\
\hline \multicolumn{10}{|c|}{ TOTAL ENERGY REQUIRED: } & 5909.60 \\
\hline
\end{tabular}


the entire region. Furthermore, our estimates of unit water use for the various crops was taken from historical data. The actual amount of water delivered to some crops in 1977 was considerably less.

Table 12 contains the monthly electricity sales to agriculture in PG \& E's service area for 1975-77. The data for 1975 and 1976 includes sales of $P G \& E$ and of other utilities in PG \& E's service area (e.g. Modesto Irrigation District, Turlock Irrigation District, Bureau of Reclamation, etc.). In addition, the total state agricultural sales are included for 1975 and 1976 as a means of comparison.

The peak demand for agriculture in PG \& E's service area occurred in July during both 1975 and 1976. The growth in electrical sales to agriculture was more than 20 percent between 1975 and 1976 reflecting a response to the first year of the drought. PG \& E's service area represented over 75 percent of the total statewide electricity sales to agriculture during both 1975 and 1976. PG \& E's agricultural peak demand for 1977 took place in August and was less than 10 percent higher than the previous year, this probably results from the shift in water supply between 1976 and 1977 (see Table 2). The total yearly sales to agriculture in 1976 were 20 percent greater than in 1975, while they increased only about 10 percent in 1977.

A graphical representation of PG \& E's electricity sales to agriculture during 1975-77 is presented in Figure 3. The graph shows a rather steady increase in electricity use from January through the peak periods in July and August followed by a steady decrease during the last quarter of the year. This pattern in total agricultural requirements corresponds to the periods when irrigation pumping demands are the greatest. The 1977 data exhibit a similar form.

Decreased water deliveries in 1977 resulted in reduced energy requirements for water pumping in both the CVP and SWP. In 1976, the CVP required 1.79 billion $\mathrm{kWh}$ for deliveries to agricultural users in the San Joaquin Valley. During 1977 the CVP used only about 800 million kWh for a savings of over 900 million $\mathrm{kWh} .^{12}$ The DWR staff reported a total net energy use of about 2.95 billion $\mathrm{kWh}$ in 1976 . This year with reductions in surface water deliveries, the estimated net energy requirements of the SWP is 1.58 billion kWh. ${ }^{13}$ These combined reductions totaled about 2.3 billion $\mathrm{kWh}$ and were a factor in P.G.GE's ability to meet peak electricity demand during the summer. 
Tab1e 12

Month1y Electricity Sales to Agriculture (1975-77) $\left(10^{6} \mathrm{kil}\right.$ owatt-hours)

\begin{tabular}{|c|c|c|c|c|c|}
\hline & \multicolumn{2}{|r|}{1975} & \multicolumn{2}{|c|}{1976} & \multirow{2}{*}{$\frac{1977}{P G \& E^{C}}$} \\
\hline & PGGE ${ }^{a}$ & Statewide & $P G E_{E}{ }^{b}$ & Statewide & \\
\hline January & 109.64 & 158.0 & 186.7 & 252.25 & 137.66 \\
\hline February & 161.60 & 219.3 & 254.51 & 333.43 & 224.86 \\
\hline March & 222.89 & 298.43 & 322.21 & 398.11 & 410.01 \\
\hline April & 285.77 & 362.1 & 432.24 & 534.22 & 462.33 \\
\hline May & 425.31 & 522.83 & 542.95 & 689.7 & 466.61 \\
\hline June & 584.17 & 723.88 & 663.22 & 838.64 & 601.84 \\
\hline July & 657.12 & 836.38 & 790.08 & 1023.99 & 803.95 \\
\hline August & 654.04 & 838.97 & 744.74 & 965.9 & 804.79 \\
\hline September & 494.54 & 674.3 & 517.29 & 712.95 & 556.07 \\
\hline October & 272.83 & 416.08 & 324.11 & 356.6 & 292.66 \\
\hline November & 130.67 & 226.34 & 160.77 & 257.58 & 200.75 \\
\hline December & 112.29 & 188.61 & 136.87 & 220.29 & 152.18 \\
\hline Yearly Total & 4110.63 & 5465.21 & 4975.69 & 6579.65 & 5113.72 \\
\hline \multicolumn{6}{|c|}{$\begin{array}{l}\text { "Electric Utility Sales Report Summary," California Energy Resources Con- } \\
\text { servation and Development Commission, 1975. Includes PGGE's sales and } \\
\text { sales of the following utilities: Bureau of Reclamation (Centra1 Valley } \\
\text { Project), City of Roseville, Modesto Irrigation District, Plumas-Sierra } \\
\text { Rural Electric, Sacramento Municipal Utility District and Turlock Irri- } \\
\text { gation District. }\end{array}$} \\
\hline \multicolumn{6}{|c|}{$\begin{array}{l}\text { b }_{\text {"Electric Utility Sales Report Summary," California Energy }} \\
\text { servation and Development Commission, } 1976 .\end{array}$} \\
\hline
\end{tabular}




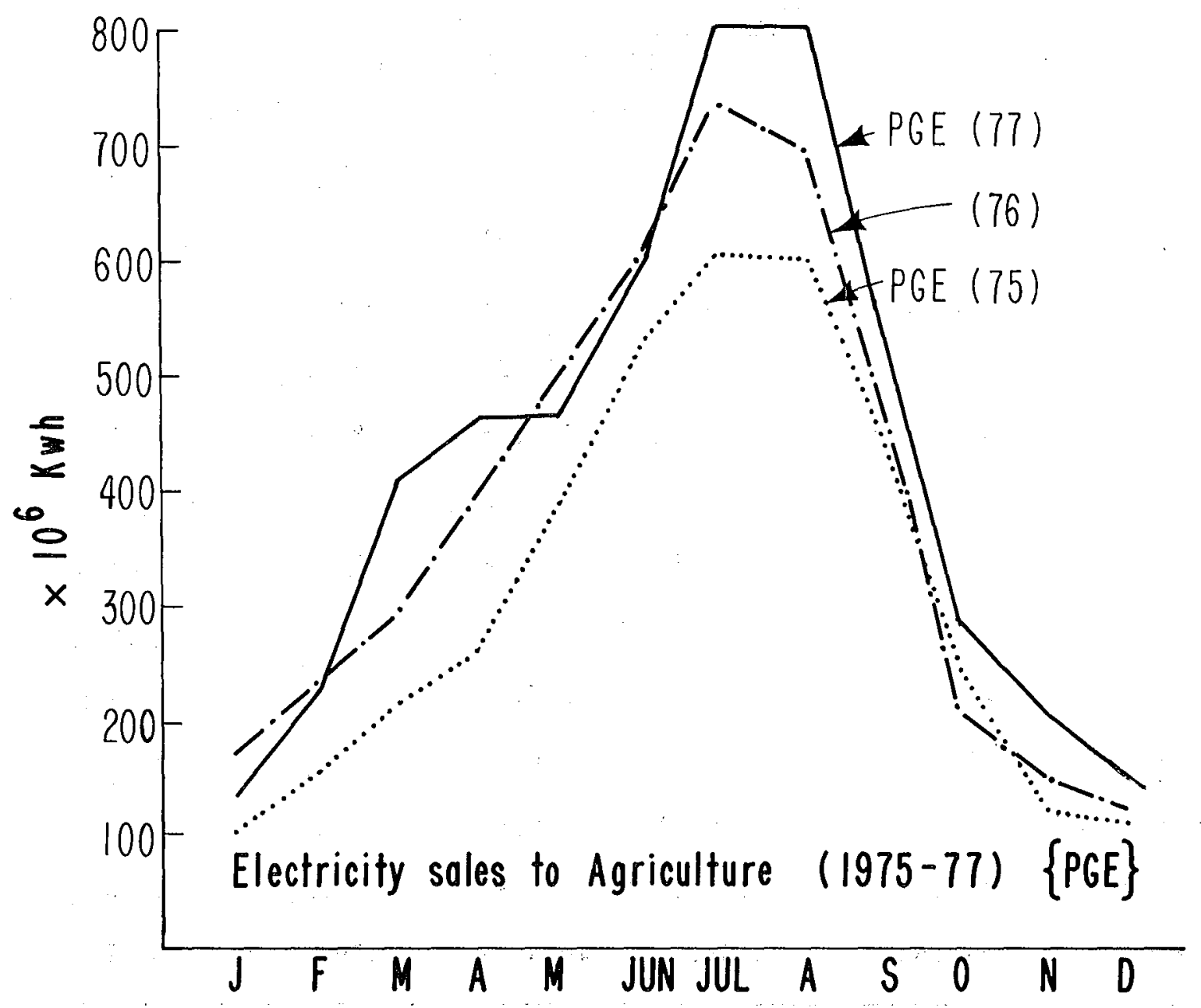

$X B L 7711-11033$

Figure 3 
AGRICULTURE'S RESPONSES TO THE DROUGHT CONDITIONS OF 1977

Although the drought-related losses to California agriculture were projected to be in a range from $\$ 500$ million to $\$ 1.5$ billion, with $\$ 800$ million the most likely figure under current conditions, the total state agricultural income is down only about one percent from last year. ${ }^{4}$ The livestock industry which is suffering from a second year of the drought, contributes an estimated $\$ 500$ miliion to the total gross farm income reductions.

The predictions earlier in the year were even more severe. The discrepancy between earlier predictions and current expectations is a result of a general underestimation of the ability of farmers to adapt to changes in their water supplies. A spokesman for the California Department of Food and Agriculture is quoted as saying "farmers behaved like farmers, while they were expected to act like economists." Furthermore, the more recent estimates were modified by the fact that about 291,000 acre-feet of water had been diverted to agriculture in the southern San Joaquin Valley from urban uses in southern California.

Increased Use of Ground Water

Farmers responded to the dry year conditions of 1977 by employing various strategies. One of the most common responses is related to the increased use of ground water. As mentioned above, growers compensated for the loss of surface water by drilling thousands of new wells, deepening existing wells and refurbishing old ground water delivery systems. Backlogs for drilling new wells and connecting to major electrical systems, however, range from three months to one year. Also, increased pumping in some areas of the state (e.g.Central Valley) have caused the water table to drop significantly. In addition to the expense of drilling a well, there are the additional energy costs to pump the ground water, especially from the increased depths. It is reported that the per unit electrical costs have more than doubled over the past five years. It costs about ten cents to 1 ift 
one acre-foot of water one foot. Therefore, it became necessary during the 1977 season to make the most efficient use of water that was available.

Increase Efficiency of Water Application

Growers are practicing "cutback irrigation," which is a management scheme that diminishes runoff and reduces deep soil percolation in furrow systems. The procedure involves a high volume initial stream to give rapid water advance down the furrow with a subsequent reduction in flow rate to maintain minimum flow. Some farmers have been collecting excess water at the ends of the fields and pumping it back to the head of the field. This return-reuse methods of surface irrigation is regarded as both an energy-and a water-efficient procedure.

Another strategy used to increase the efficiency of water application has been the change in irrigation methods during 1977. There has been an increase in the installation of sprinkler and drip systems. These changes involved large expenditures of capital and certain delays related to the time necessary to design, order and install the new irrigation systems. Although a net decrease in water use may result from the use of sprinkler and drip systems, their implementation may lead to increased energy use depending on the water source that is employed. A discussion of the relationship between water and energy efficiencies of the various irrigation methods will be given in a later section of this report.

\section{Reduce Water Application}

"Deficit irrigation," which is simply the application of less water than usual, is taking place in answer to the dry year conditions. The application of less water, in turn, reduces surface evaporation and more importantly evapo-transpiration, which accounts for the greatest loss of water by a crop. Instead of totally replacing these losses through irrigation, the level of soil moisture is allowed to be depleted. On the other hand, the relationship between crop yield and water 
stress is a very critical one, which must be considered when determining the optimal amount of water to apply to the plant system. The water status of a plant is only one factor in crop production, although a very important one, especially in a drought.

A technique being used in relation to reduced supplies of water is that of "minimized leaching." Additional water above that needed to replace the loss from evapo-transpiration is applied to balance salt levels in the crop's root zone. This additional water, which is crucial to good irrigation management, is called the leaching requirement. The amount of leaching requirements have been reduced drastically in some areas of the state. Minimized leaching will save more irrigation water, but its use is still untested on a large scale and over long periods of time. Actual1y, what has happened over the past two dry years is that leaching has been postponed. The future status of this water conservation strategy is unknown at this time.

Cropping Pattern Changes in 1977

Although water available from the SWP in 1977 was cut back nearly 50 percent from last year, irrigated acreage was reduced only 13 percent on a statewide basis. 4 The 1977. crop patterns show decreases in acreage for some commodities and increases in others. These changes reflect not on 1y the drought situation but also market conditions.

Table 13 shows planted acreages of selected crops for the 1975 and 1976 growing seasons along with estimated plantings in 1977. The largest acreage reductions from 1976 were for sorghum ( 37 percent), sugar beets $(-26$ percent), rice $(-18$ percent), wheat $(-12$ percent $)$, and corn ( -10 percent). The production of these crops decreased not on $1 y$ because of diminishing supplies of water but due to lower prices resulting from sizable global stocks of food and feed grains.

The reduction in sorghum is probably directly related to the drought since sorghum is frequently grown as a second crop. During this drought year a second crop was not grown in many parts of the state. Unprofitable prices and the drought are responsible for the reduced 1977 sugar beet acreage. This reduction is also due to the two-year sugar 
beet crop rotation problem. Rice, which as a higher average annual applied water requirement than any other crop, was replaced in some areas with oats, safflower and tomatoes.

Cotton plantings have increased about 19 percent over last year because of a favorable market and government price supports. Furthermore, cotton requires lower quality water and its deep roots use moisture deep in the soil profile. Cotton acreage is 1.35 million acres which is the largest planting since 1953. Planting in some areas of southern California increased about 95 percent over 1976, because of favorable market price induced by an uncertainty of water supplies in the San Joaquin Valley. The Central Valley's cotton yield, however, was less as a consequence of the diminished supply of water for irrigation. Planted acreage of oats and alfalfa also increased slightly over 1976.

Most fruit and nut crops, which generally have access to ground water supplies, are expected to survive, although yields will probably be lower. Some citrus crops (e.g. oranges), however, can not tolerate drought conditions. There is the possibility that some groves may be lost in the San Joaquin Valley.

Since most vegetables are produced in southern California or along the central coast where water supplies are not significantly affected by the drought, vegetables are probably the least affected acricultural sector. Planted acreage of processing tomatoes, which supplies approximately 80 percent of the nation's market, is up 5 percent from last year. While growing of tomatoes requires more water per acre than most vegetable crops, the market price increased from $\$ 47$ to $\$ 55$ a ton, thus making them a favorable crop. Tomato acreage increased by about 13,000 acres over the 1976 acreage to 200,000 acres.

Future Problems Created During the Drought

Several problems may have been created by obtaining the needed water supplies for 1976-1977. In order to make up some of their surface water deficiencies, farmers relied on ground water pumping. 
Table 13

Plantings of Selected Crops in California (1975-77) $\left(10^{3}\right.$ acres $)$

\begin{tabular}{|c|c|c|c|c|}
\hline Crop & $1975^{a}$ & $1976^{b}$ & $\begin{array}{l}\text { Estinated } \\
1977^{\mathrm{C}}\end{array}$ & $\begin{array}{l}\text { Estimated } \\
1976-77\end{array}$ \\
\hline \multicolumn{5}{|l|}{ Field Crops } \\
\hline Alfalfa & 1650 & 1630 & 1670 & +2 \\
\hline Barley & 1220 & 1200 & 1150 & -4 \\
\hline Beans & 154 & 179 & 176 & -2 \\
\hline Corn & 420 & 480 & 430 & -10 \\
\hline Cotton & 900 & 1120 & 1350 & +19 \\
\hline Oats & 365 & 385 & 400 & +4 \\
\hline Potatoes & 15 & 16. & 16 & +0.6 \\
\hline Rice & 530 & 421 & 345 & -18 \\
\hline Sorghum & 230 & 235 & 150 & -37 \\
\hline Sugar Beets & 333 & 318 & 235 & -26 \\
\hline Wheat (excluding Durum) & 1060 & 1000 & 885 & -12 \\
\hline Wheat (Durum) & 15 & 90 & 30 & -67 \\
\hline Fruit/Nuts $^{d}$ (excluding grapes) & 1335 & 1335 & 1335 & -- \\
\hline Grapes & 647 & 631 & 647 & -- \\
\hline $\begin{array}{l}\text { Vegetables } \\
\text { (excluding tomatoes) }\end{array}$ & 616.1 & 555.7 & 620 & +12 \\
\hline Tomatoes & 305.6 & 267.7 & 280 & +5 \\
\hline \multicolumn{5}{|c|}{ 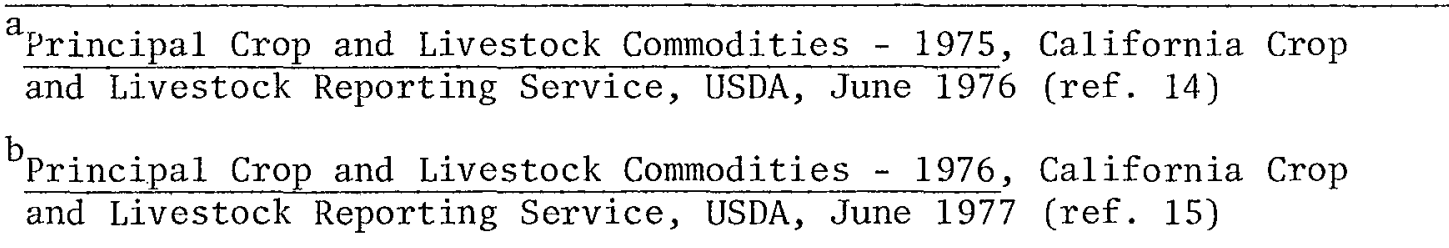 } \\
\hline \multicolumn{5}{|c|}{$\frac{{ }^{c} \text { Crop Intentions Report, Ca1ifornia Crop and Livestock Reporting }}{\text { Service, USDA, June } 1977 \text { (ref. 16) }}$} \\
\hline
\end{tabular}



A heavy reliance on ground water pumping, however, is accompanied by potential adverse effects such as well collapse, ground subsidence and the possibility of wells going dry.

A further problem with the extensive use of ground water sources in a drought year is that of future recharge rates. Natural recharge has decreased about 45 percent over the past two years, while percolation from applied water sources has decreased about 26 percent. On the other hand, ground water overdraft has increased from a level of about 2.1 million acre-feet in 1975 to an estimated 10 million acre-feet in 1977. Overdraft and ground subsidence lead to a collapse of ground formation which reduces the water storage capacity. In view of the needs and the possibility of future drought periods, the replenishment of ground water basins is a problem requiring consideration at some future time.

In an attempt to conserve water during 1977 less frequent irrigations were made with less applied water per application. The effect of the drought is to put both annual crops (e.g. field crops) and perennials (e.g. trees and vines) under stress. The problem is most serious for the perennials. It is not known at this time what the effects of last year's dry conditions were on the life of the trees and vines. In addition, the future yields of the perennial crops may be affected in 1ater years.

Another problem with reduced water applications and rates is that there is less soil moisture carry over into the next growing season. In addition, reduced water application together with the use of a lower quality of water for irrigation may result in more severe soil salinity problems in the future. For a permanent irrigated crop, salt must be removed from the soil at the same rate it is introduced by irrigation water, otherwise a steadily increasing salt concentration in the soil water will cause a progressive reduction in crop yields. The relationship between reduced water application, soil salinity and ground water as they apply to the total salt balance picture is a critical question that needs to be considered. 
CONSERVATION OF ELECTRICITY AND WATER IN THE AGRICULTURAL SECTOR

Factors in Agricultura1 Resource Use

The drought conditions of 1976-77 have shown both the necessity and ability to conserve water in agriculture, as well as in other sectors of our society. Because of the use of energy for water delivery and use, water conservation can mean energy conservation as well, though this is dependent on the irrigation method used (see section on Water Efficiency in the Fie1d). In a drought year the lack of surface water supply is partially made up by increased ground water pumping, which increases electricity consumed, though not as greatly as if water conservation is not being practiced. In a normal rainfall year, the electricity savings associated with water conservation could be as much as 25 percent. 20

The requisites for implementation proceed on many levels. Some measures, such as cutback irrigation, require only a change of practice on the part of the farmer. Some strategies begin to involve other sectors through the purchase and installation of equipment or the change of labor schedules. At the widest extreme, a change of governmental policy may be required. While many conservation strategies are implemented ultimately on the farm, the policies and practices of broader levels of organization (e.g. water districts or the federal government) can effect the facilitation of the necessary changes.

The relationship between energy conservation and water conservation in agriculture is fairly complex. Certain aspects, such as pump and we11 efficiency, are independent of water use. The electricity used in water delivery and application is dependent on a variety of factors, e.g. irrigation system, crop, weather and local growing conditions. Depending on the specifics of the situation, more or less energy may be required to apply the same amount of water.

The water-energy equation has another factor which is labor. Traditionally, the large quantities of water used in irrigation substitute for 1abor,i.e. for arranging irrigation systems in the field, for maintaining those systems, for scheduling according to need and efficiency rather than convenience. In changing to more efficient irrigation methods, there are the major barriers of increased cost and of low availability of labor needed to implement the methods. 
Some measures such as minimal leaching are explicitly short term in application because of their cumulative adverse effects. Other measures can be incorporated into a continuing conservation effort since the increasing water demands will affect water price and availability. Generally, the more elaborate the physical set-up, the longer the lead time needed to. implement the measure.

\section{Types of Strategies}

There are several general approaches to agricultural electricity conservation which cover a variety of individual strategies. The dimensions in which these approaches vary are level of implementation and method of balancing water or electrical supply and demand. These approaches are:

- Maintaining and augmenting surface water supply

- Decrease in electricity demand

- Power use efficiency

- Shifting power demand

- Decrease in water demand

- Water efficiency in the field: retention, uniform application, proper amount of application

There are two overriding caveats to this discussion of strategies. First are the limits to the usefulness of the strategies, not only in terms of lead time, technological development and cost, but a1so in terms of geographic factors such as soil, climate, local social and economic structure, and marketing of crops. Nearly a11 (90 percent) of the energy used for irrigation is used in the 7 hydrologic basins that contain over 90 percent of California's agriculture. ${ }^{21}$ Regional energy requirements for pumping vary (see Tables 14 and 15). The second caveat is the quality of the information presented. Since the data were gathered from a variety of sources, there is a lack of uniformity between the strategies. In some cases, the figures given are estimates, while in others, they are not given because of a lack of information. But most importantly the data do not represent the same geographic regions and therefore care must be taken in applying the results to a region with a different character. 
Table 14

Irrigation Pumping Energy for Selected Hydrologic Basins

\begin{tabular}{llc}
\hline $\begin{array}{c}\text { Hydrologic Basin } \\
\text { Planning Areas }\end{array}$ & $\begin{array}{c}\text { Agricultural Irrigation } \\
\text { Pumping }\end{array}$ \\
\hline 1A & Klamath River & 3.1 \\
3 & Centra1 Coast & 0.1 \\
$5 A$ & Sacramento River & 5.1 \\
5B & Sacramento - San & 9.6 \\
& Joaquin Delta & 4.4 \\
$5 C$ & San Joaquin & 14.6 \\
5D & Tulare Lake & 49.6 \\
7A & West Colorado River & 5.0 \\
\hline
\end{tabular}

Source: Reference 21, Table 3, p. 40.

Table 15

1976 Pump Lift and Efficiency Tests

\begin{tabular}{|c|c|c|c|c|c|c|c|c|c|}
\hline \multirow{2}{*}{ District } & \multicolumn{3}{|c|}{$\mathrm{kWh} / \mathrm{AF}$} & \multicolumn{3}{|c|}{$\begin{array}{l}\text { Average Overa } 11 \\
\text { Plant Efficiency }\end{array}$} & \multicolumn{3}{|c|}{$\begin{array}{l}\text { Average Total } \\
\text { Lift in Feet }\end{array}$} \\
\hline & 1974 & 1975 & 1976 & 1974 & 1975 & 1976 & 1974 & 1975 & 1976 \\
\hline Kings & 345 & 295 & 329 & 53.1 & 55.8 & 55.5 & 179 & 138 & 124 \\
\hline Fresno & 173 & 245 & 229 & 54.6 & 56.4 & 54.9 & 92 & 138 & 124 \\
\hline Kern & 569 & 594 & 630 & 57.8 & 58.2 & 55.3 & 321 & 304 & 315 \\
\hline Yosemite & 223 & 237 & 230 & 55.3 & 58.5 & 56.6 & 120 & 135 & 133 \\
\hline $\begin{array}{l}\text { San Joaquin } \\
\text { Division }\end{array}$ & 344 & 340 & 362 & 553 & 575 & 55.8 & 186 & 178 & 173 \\
\hline
\end{tabular}

Source: PGGE 1976 Pumping Lift Report. 
The individual strategies have been evaluated in terms of lead time, costs, potential savings and limiting criteria. These characteristics for each strategy are summarized in Table 16 which covers all the approaches listed above. The rest of this section consists of a discussion of those strategies which are relevant to direct electricity conservation in California and which can be implemented in the future. Other strategies, while important to continuing conservation, are not discussed for 1ack of space. For clarity in the discussion, some of the strategies are discussed together in one section to avoid unnecessary cross references. It should be noted that the strategies do not represent a disconnected course of action. Many of them must be combined in order to achieve water and energy conservation while maintaining crop yields.

Maintaining and Augmenting Surface Water Supply

Reducing Evaporation and Percolation Losses

Many of the canals and ditches used to deliver water are unlined and uncovered. Water evaporates from the surfaces and percolates into the ground as there is no barrier. Often these canals and ditches have phreatophytes or water-loving plants growing in them. These plants increase water loss through high transpiration rates. Eliminating phreatophytes would slightly increase ground water recharge ${ }^{10}$ but the use of herbicides and the loss of wild1ife habitats may counter the water savings. While covering the surfaces to prevent evaporative loss aids in water management, the prevention of percolation by lining is a more complex issue. Percolation is necessary to maintain both ground water supplies and the underground storage capacity. Large and 1ong depletion cause capacity reduction. Where pumping energy is a critical factor however, the cost of recovering percolated water from the ground may make canal lining desirable.

Similar issues are involved in the building of storage reservoirs. They have water loss from ground and surface, though they can be lined and covered. Additiona11y, if they are built in proximity to the area where the water will be used, good land may be taken out of production. The great advantage of reservoirs is that they allow greater flexibility in scheduling irrigation. 
Table 16

Strategies of Agricultural Electricity Conservation

\begin{tabular}{|c|c|c|c|c|}
\hline Strategy & $\begin{array}{c}\text { Time of } \\
\text { Implementation }\end{array}$ & Costs & $\begin{array}{l}\text { E1ectricity } \\
\text { Savings }\end{array}$ & $\begin{array}{l}\text { Implementation } \\
\text { Criteria }\end{array}$ \\
\hline \multicolumn{5}{|c|}{ A. Maintaining and Augmenting Surface Water Supply } \\
\hline $\begin{array}{l}\text { Phreatophytic } \\
\text { control }\end{array}$ & now & $\begin{array}{l}\$, \text { ecological } \\
\text { alteration }\end{array}$ & $\begin{array}{l}\text { Through water } \\
\text { savings }\end{array}$ & \\
\hline $\begin{array}{l}\text { Ditch and canal } \\
\text { lining \& covering }\end{array}$ & $\begin{array}{l}\text { now - a few } \\
\text { months }\end{array}$ & $\begin{array}{l}\text { High capital } \\
\text { cost }\end{array}$ & $\begin{array}{l}210 \% \text { water } \\
\text { savings } 10\end{array}$ & Loss of percolation \\
\hline $\begin{array}{l}\text { Use of reclaimed } \\
\text { water }\end{array}$ & $4-8$ years $^{20}$ & $\begin{array}{l}\text { Capital } \\
\text { investment }\end{array}$ & $\begin{array}{l}5-10 \% \text { water saving } \\
\text { energy cost in } \\
\text { processing }\end{array}$ & $\begin{array}{l}\text { Dependent on basin } \\
\text { hydrology and } \\
\text { topography }\end{array}$ \\
\hline
\end{tabular}

B. Decreasing Electricity Demand

\begin{tabular}{|c|c|c|c|c|}
\hline $\begin{array}{l}\text { Solar-powered } \\
\text { pumps }\end{array}$ & a few years & $\begin{array}{l}\text { Research and } \\
\text { Capital } \\
\text { investment }\end{array}$ & $\begin{array}{l}\text { Some, could be } \\
\text { considerable }\end{array}$ & $\begin{array}{l}\text { Needs backup power } \\
\text { source }\end{array}$ \\
\hline $\begin{array}{l}\text { Wind-powered } \\
\text { pumps }\end{array}$ & $\begin{array}{l}\text { now - a few } \\
\text { years }\end{array}$ & $\begin{array}{l}\text { Capital } \\
\text { investment }\end{array}$ & $10-15 \% 20$ & $\begin{array}{l}\text { Needs backup power } \\
\text { source; some old } \\
\text { mills can be } \\
\text { reconnected }\end{array}$ \\
\hline $\begin{array}{l}\text { Diese1-powered } \\
\text { pumps }\end{array}$ & now & $\begin{array}{l}\text { Capital } \\
\text { investment }\end{array}$ & Some & $\begin{array}{l}\text { Basin air quality; } \\
\text { necessary where no } \\
\text { electrical hookup } \\
\text { available }\end{array}$ \\
\hline $\begin{array}{l}\text { Crop residue } \\
\text { as fuel }\end{array}$ & 6 years $^{20}$ & $\begin{array}{l}\text { Research and } \\
\text { development }\end{array}$ & $60 \%$ & $\begin{array}{l}\text { Reduces material } \\
\text { available for } \\
\text { organic mulch }\end{array}$ \\
\hline $\begin{array}{l}\text { Cogeneration on } \\
\text { distribution } \\
\text { canals }\end{array}$ & now & $\begin{array}{l}\text { Capital } \\
\text { investment }\end{array}$ & Some & $\begin{array}{l}\text { Need sufficient } \\
\text { drop to generate } \\
\text { electricity }\end{array}$ \\
\hline \multicolumn{5}{|c|}{ C. Power Use Efficiency } \\
\hline We11 Maintenance & now & $\begin{array}{l}\text { Capital } \\
\text { investment }\end{array}$ & Some & $\begin{array}{l}\text { Best for new wells, } \\
\text { also reactivated } \\
\text { wells }\end{array}$ \\
\hline Well efficiency & $4-7$ years $^{20}$ & Research & $2-10 \% 20$ & \\
\hline Pump maintenance & now & Service fee & $\begin{array}{l}15-35 \% 20 \\
\text { probably } 15 \%\end{array}$ & $\begin{array}{l}\text { Especially for } \\
\text { pumps older than } \\
5 \text { years }\end{array}$ \\
\hline $\begin{array}{l}\text { Pump and motor } \\
\text { efficiencies }\end{array}$ & 5 years $^{20}$ & $\begin{array}{l}\text { Research and } \\
\text { capital } \\
\text { investment }\end{array}$ & $2-5 \% 20$ & $\begin{array}{l}\text { Big pumps are more } \\
\text { efficient }\end{array}$ \\
\hline D. Shifting Power & Demand & & & \\
\hline Winter irrigation 1 & now & $\begin{array}{l}\text { Less water- } \\
\text { efficient }\end{array}$ & $\begin{array}{l}\text { Possibly increase } \\
\text { pumping }\end{array}$ & $\begin{array}{l}\text { Especially for soils } \\
\text { with high water } \\
\text { retention, also for } \\
\text { salt leaching }\end{array}$ \\
\hline Weekend pumping & now & $\begin{array}{l}\text { Change in labor } \\
\text { schedule }\end{array}$ & & $\begin{array}{l}\text { Physical system may } \\
\text { limit }\end{array}$ \\
\hline Night pumping & now & Labor & $\begin{array}{l}\text { Need for night } \\
\text { lighting }\end{array}$ & $\begin{array}{l}\text { Most feasible from } \\
\text { storage facility }\end{array}$ \\
\hline
\end{tabular}


Table 16 (continued)

\begin{tabular}{lllll}
\hline Strategy & $\begin{array}{c}\text { Time of } \\
\text { Implementation }\end{array}$ & Costs & $\begin{array}{c}\text { Electricity } \\
\text { Savings }\end{array}$ & $\begin{array}{c}\text { Implementation } \\
\text { Criteria }\end{array}$ \\
\hline
\end{tabular}

E. Decreasing Water Demand in the Field

$\begin{array}{llll}\text { Winter fallow } & \text { now } & \begin{array}{l}\text { Lower crop } \\ \text { yield }\end{array} & \text { From not pumping } \\ \begin{array}{l}\text { Removing marginal } \\ \text { land from } \\ \text { production }\end{array} & \text { now } & & \text { Less pumping }\end{array}$

Reduced

application

now

F. Water Efficiency in the Field

\begin{tabular}{|c|c|c|c|}
\hline Cutback irrigation & now & Labor & $\begin{array}{l}\text { Through water } \\
\text { savings }\end{array}$ \\
\hline Tailwater reuse & now & See Table 21 & $\begin{array}{l}\text { See Table } 20 \\
\text { and Figure } 4\end{array}$ \\
\hline Sprinkler systems & a few months & See Table 21 & $\begin{array}{l}\text { See Table } 20 \\
\text { and Figure } 4\end{array}$ \\
\hline Drip & a few months & See Table 21 & $\begin{array}{l}\text { See Table } 20 \\
\text { and Figure } 4\end{array}$ \\
\hline Gated pipe & months & $\begin{array}{l}\text { Capital and } \\
\text { labor }\end{array}$ & $\begin{array}{l}\text { Through water } \\
\text { savings, very } \\
\text { smal1 energy } \\
\text { cost }\end{array}$ \\
\hline $\begin{array}{l}\text { Irrigation } \\
\text { management }\end{array}$ & now & $\begin{array}{l}\text { Labor; servic } \\
\text { fee, } \$ 5-6 \text { acr }\end{array}$ & $25 \% 20$ \\
\hline
\end{tabular}

Legal Constraints, marginal land has high irrigation and leaching requirements than prime land

Cost of $\quad$ Through $10 \%$
measurement water savings 20
and scheduling.

Allow programmed depletion of available soil moisture

Great1y improves water use efficiency of surface irrigation and leaching uniformity

Benefit depends on basin hydrology, water costs and topography

Benefit depends on well depth; can increase plant disease; inefficient in desert areas

Not for use in extreme soil types; most profitable for high value crops

Prevents erosion on steep slopes; increase areal distribution from single water source

Limited trained personnel, tailored to site, increased yield offsets fee 
Using Reclaimed Waste Water

Substituting water reclaimed from industrial and municipal use for fresh water in agriculture is possible because a lower water quality is required for thosecrops not directly consumed by people. Secondary sewage treatment is required for ocean disposal and tertiary for river disposal, making the water usable for fiber and forage and in some cases orchard crops. While the energy cost of reclamation, equivalent to 3 bbl of oil per acre-foot has been compared to that of ground water pumping, $1 / 2$ bbl of oil. ${ }^{22}$ Such blanket comparisons ignore the fact that some water treatment is required for any disposal, Given that treated water is available for irrigation, the savings in terms of energy for ground water pumping has been estimated to be around 5-10 percent. ${ }^{21}$ Water slated for disposal must be pumped to, the fields. In the case of ocean disposal, there is little nearby agricultural land and ranges of hills between treatment plant and irrigated farm land. The amount of treatment required for various agricultural purposes and the elevation change to delivery point determine if energy can be saved by using waste water. Another complication in evaluating the impact of waste water irrigation is that transferring water from one hydrologic basin to another may lower the water, table of the supplying area.

\section{Decrease in Electricity Demand}

Changing Pump Power Source

One way to reduce electricity demandis to use an alternate power source. Diesel pumps are used where electricity hookups are unavailable as in Westlands Water District, but they are somewhat less convenient than electric pumps, easier to overload, and are more expensive. ${ }^{21}$ Furthermore, depending on the air basin, air quality may be concern. In terms of direct energy utilization, electric pumps are more efficient, but in terms of total energy input that advantage is dependent on the generation efficiency (see Table 17). 
Table 17

Energy Required to Lift One Acre-Foot Water One Foot (agricultural deep-well pumping plants)

\begin{tabular}{|c|c|c|c|}
\hline & \multicolumn{2}{|c|}{$\begin{array}{l}\text { Direct Energy Input } \\
\text { to Pumping Plant }\end{array}$} & \multirow{2}{*}{$\begin{array}{c}\begin{array}{l}\text { Total Primary } \\
\text { Energy }\end{array} \\
\text { Btu/AF/ft }\end{array}$} \\
\hline & Fue $1 / \mathrm{AF} / \mathrm{ft}$ & $\mathrm{Btu} / \mathrm{AF} / \mathrm{ft}$ & \\
\hline \multicolumn{4}{|l|}{ Nebraska Standard Performance } \\
\hline \multicolumn{4}{|l|}{ Electricity } \\
\hline (.38 generation efficiency) & $1.55 \mathrm{kWh}$ & 5,290 & 17,200 \\
\hline (.31 generation efficiency) & $1.55 \mathrm{kWh}$ & 5,290 & 21,100 \\
\hline (.25 generation efficiency) & $1.55 \mathrm{kWh}$ & 5,290 & 26,100 \\
\hline Natural Gas & $20.5 \mathrm{ft}^{3}$ & 21,900 & 24,000 \\
\hline Diese1 & $0.125 \mathrm{gal}$ & 17,500 & 20,400 \\
\hline Gasoline & $0.158 \mathrm{gal}$ & 19,600 & 22,900 \\
\hline Propane & $1.199 \mathrm{gal}$ & 18,300 & 21,400 \\
\hline \multicolumn{4}{|l|}{ Nebraska Observed Average } \\
\hline \multicolumn{4}{|l|}{ Electricity } \\
\hline (.38 generation efficiency) & $1.96 \mathrm{kWh}$ & 6,690 & 21,700 \\
\hline (.31 generation efficiency) & $1.96 \mathrm{kWh}$ & 6,690 & 26,600 \\
\hline (.25 generation efficiency) & $1.96 \mathrm{kWh}$ & 6,690 & 33,000 \\
\hline Natural Gas & $35.4 \mathrm{ft}^{3}$ & 37,800 & 41,500 \\
\hline Diesel & $0.172 \mathrm{gal}$ & 24,100 & 28,100 \\
\hline Gasoline & $0.278 \mathrm{gal}$ & 34,500 & 40,200 \\
\hline Propane & $0.336 \mathrm{gal}$ & 30,900 & 36,100 \\
\hline
\end{tabular}

Source: Reference 21. 
Solar and wind-powered pump development offer the opportunity for substantial energy savings in the near future. Currently, old wind mills can be reconnected. The major drawback to these power sources is the need for a backup power source involving additional capital investment which most farmers cannot afford. Water generated power from drops along the cana1s can supply energy to the nearby distribution pumps if the height is sufficient, six to eight feet.

Power Use Efficiency

We11 Efficiency \& Maintenance

The amount of energy necessary to lift a given volume of water depends not only on the well depth, but also on the we11 efficiency. An efficient we11 is one which has an even, loose distribution of particles between gravel. When the fine particles form clots, more power is needed to draw water out of the well. The particles are silt and clay which are common in the soil types in California. This problem can be ameliorated by pumping the well in surges. Other remedies include acid treatments, new casing and gravel pack. It is important that the well be drilled properly in the first place and that it be maintained to gain maximum efficiency. Either a meter for a well $\log$ or an observation wel1 to measure the draw down is required in order to determine we11 efficiency. A program to upgrade we11s and standardize the drilling of new wells could be implemented in the next year.

Pump Efficiency and Maintenance

Many pumps have lower efficiencies because they are out of tune. Efficiency tends to be fairly high for the first five years of operations, but drops sharply after that. ${ }^{23}$ (See Table 18). A tune-up will improve the efficiency and should last three years, which is about the time necessary for the energy savings to balance the cost. 24,25 A more thorough investigation shows that the cross-over point between costs and benefits varies with the units of analysis. ${ }^{25}$ In monetary terms, pumps should be rebuilt after 5 years; in energy terms, it should be done after 2 years. 
Tab1e 18

Number of Pumping Plants at a Level of Performance by $\mathrm{Age}^{\mathrm{a}}$

\begin{tabular}{cccccccccccc}
\hline $\begin{array}{c}\text { Efficiency* } \\
(\%)\end{array}$ & 1 & 2 & 3 & 4 & 5 & 6 & 7 & 8 & 9 & $\begin{array}{c}10 \\
\text { or } \\
\text { More }\end{array}$ & Total \\
\hline$>88$ & 4 & 9 & 7 & 1 & 7 & 1 & 0 & 0 & 0 & 1 & 30 \\
$80-88$ & 13 & 13 & 6 & 6 & 3 & 4 & 2 & 1 & 1 & 1 & 50 \\
$66-79$ & 11 & 33 & 22 & 18 & 9 & 8 & 6 & 1 & 2 & 11 & 121 \\
$44-65$ & 8 & 17 & 20 & 14 & 8 & 7 & 5 & 1 & 4 & 17 & 101 \\
$<43$ & 3 & 6 & 3 & 4 & 0 & 0 & 3 & 1 & 0 & 10 & 30 \\
TOTAL & 39 & 78 & 58 & 43 & 27 & 20 & 16 & 4 & 7 & 40 & 332 \\
\hline
\end{tabular}

Source: Reference 23

$a_{44}$ units did not have age known.

*of $100 \%$ possible

Table 19

Number of Pumping Plants Attaining a Leve1 of Performance with Various Pumping Lifts

\begin{tabular}{|c|c|c|c|c|c|}
\hline $\begin{array}{c}\text { Efficiency* } \\
\left(\begin{array}{l}\% \\
\%\end{array}\right)\end{array}$ & $50^{\prime}$ or Less & $50^{\prime}-100^{\prime}$ & $100^{\prime}-200^{\prime}$ & $200^{\prime}$ or Over & Tota 1 \\
\hline 88 & 2 & 7 & 11 & 14 & 34 \\
\hline $80-88$ & 1 & 12 & 32 & 10 & 155 \\
\hline $66-79$ & 20 & 30 & 53 & 29 & 132 \\
\hline $44-65$ & 39 & 37 & 39 & 6 & 121 \\
\hline TOTAL & 82 & 95 & 139 & 60 & 342 \\
\hline
\end{tabular}

Source: Reference 23

* of $100 \%$ possible 
The weighted average pump efficiency in California is 50 percent. This average is weighted for pump capacity since larger pumps are generally more efficient. The pump efficiency could easily be improved to 65-70 percent, which would yield a 15 percent energy saving. ${ }^{25}$ The higher efficiency of large pumps also is represented in efficiency levels for pumping from varying depths (Table 19).

\section{Shifting Power Demand}

Winter Irrigation

The peak energy demand for agricultural pumping occurs in July and August generally at the same time that power use peaks. As the purpose of irrigation is to supply water for crop growth, making the water available in a manner other than direct application can alter the agricultural power demand curve. By irrigating during the winter and early spring, it is possible to raise the soil moisture to field capacity at the start of the growing season. ${ }^{26}$ This strategy is appropriate for clay soils, such as are predominant in California, since they retain their moisture over a fairly long time. This would shift the pumping load to a time when there will be less demand from other sectors. It would also be possible to coordinate water ixrigation with spills from reservoirs in preparation for flood control. Possible drawbacks to this strategy are the legal and institutional constraints on release scheduling and the depletion of reservoirs at a time when general demand for hydroelectric power is lower.

Weekend Pumping

Another shift of power demand could be away from the mid-week peak. ${ }^{27}$ In terms of institutional organization, physical capacity of the delivery system, and crop growth stage there may be some difficulties scheduling releases for the weekend. Farmers may be reluctant to accept such a schedule or may not be able to find the labor to implement it. Some operations currently pump week-round as a minimum flow.over maximum time 
is most energy efficient. However, it does offer a compromise between current irrigation practices and a restriction to off-peak pumping as well as lessening some of the problems of night pumping.

Night Pumping

There are many problems and barriers for this strategy. There are difficulties with scheduling labor, system capacity (some fields require 24-hour pumping to irrigate completely), storage facilities, and restart adjustments. A severe effect of pumping a well only at night is the increased periodic draft of aquifers. In order to obtain the same volume, a greater flow rate is necessary which can aggravate saltwater intrusion where saltwater aquifars neighbor fresh ones. 28 In some irrigation set-ups, storage is necessary and already established. In the case of low yield well which need to be constantly pumped to accumulate enough water for irrigation, application pumping from a storage pond or tank can be done at night. Where the drainage water has been collected for reuse, the relift pumping can also be done at night.

Decrease in Water Demand

Reducing Water App1ication

The relationship between the amount of water applied and crop yield is a direct one up to the limit of the maximum transpiration.. The more water applied, the greater the yield is except when the crop is over irrigated and root damage results. There are a couple of circumstances when over-irrigation is likely to occur, if there is a long lag time between water application and the adverse effect of over-irrigating. With alfalfa, the initial effect is to increase production, but over time the stand loses its vigor and is invaded by native grasses sooner than a properly watered field. If the water supply is from a river which drops its level in the middle of the irrigating season, the irrigator may irrigate hovily early in the season in an attempt to compensate for lack of water later. The important thing to do is to bring the soil moisture to its maximum just before the river drops. 
Reducing water application below the maximum plant use level may cause a drop in yield tonnage. In the case of orchard and vine rops such reduction may bring about improvement in flavor and shipping characteristics. When water application is reduced below the amount needed to replace water lost through evapo-transpiration and percolation, the soil moisture is depleted, though the plants begin to transpire less. A program of soil water depletion can be coordinated with crop growth stages to minimize adverse effects, but there are limits to this strategy. When leaching is cut, the soil salinity rises and interferes with crop growth especially during the period of germination. This problem is more severe in areas where the soil has a high salt content In areas where the irrigation water has a high salt content or the drainage is poor and salts accumulate in the soil, reduced water application can be beneficial by delivering less salt and reducing the chemical reactions which produce salts. Depletion of soil moisture is possible only with deep rooting crops which have a large enough root area to draw the water needed for growth. Last summer there were some reductions of applied water. While this demonstrates a willingness to use this strategy, it may limit the applicability for next summer, in terms of accumulated soil salts and current low soil moisture levels. One way to maintain soil moisture and to minimize risk of over-depletion is to apply mulch to the surface. Reduction of water loss (ranging from 16 percent to 49 percent) has been reported. ${ }^{29}$ There is a point however, at which additional mulch does not affect moisture retention. Effectiveness and choice of mulch depend to some extent on the crop, the weather pattern and the soil. There is also a minimal application below which mulching has no effect. The tradeoff between cost and energy savings is unknown, but implementation is readily accomplished. Mulching also reduces the salt concentration in the soil.

Water Efficiency in the Field

Tailwater Reuse

In a gravity or flow fed system without return flow, only part of the water is actually used by the plant. By pumping the excess back 
to the field, the water can be reused. Such systems are already employed extensively in the San Joaquin Valley. The energy budget of a return flow system depends on size and slope of the field and the depth from which water is pumped. The deeper the well, the more efficient it is to reuse the water. This strategy also entails the installation of sumps for collecting the runoff. The water of the final runoff has high total dissolved solids. Implementing this method requires additional labor and time. The time involved depends on the current physical layout of the fields. A tailwater reuse system with proper use can compare favorably with sprinkler systems. ${ }^{21}$ The water use efficiency is improved from 65 percent for regular furrow irrigation to 81 percent by reusing $1 / 4$ to $1 / 3$ of the water. Another advantage is control of those plant diseases which are spread through run-off. In many districts, it is not necessary for the farmers to reuse tailwater to achieve a high district water efficiency. Often the irrigation district collects the run-off and either relifts it or sells it downslope to other users.

The energy relations which depend on the water availability and topography are more complex. In terms of pumping energy and we11 depth, tailwater reuse becomes advantageous deeper than 25 feet. ${ }^{21}$ If the water table is not extremely deep or if water is not transported over mountains (as for San Diego and Los Angeles Hydrologic Basins), the additional energy to pump tailwater to the top of the field increases the total energy requirement for irrigation on a basin wide average.

Sprinkler, Drip and Gated Pipe Irrigation

Sprinklers apply water more efficiently by allowing better penetration of the water into the ground. Pressurizing the water to disperse it requires pumping energy. If the water is pumped from deeper than 300 feet, the less water used, the more economical, so that the smaller energy cost of sprinkler pressure becomes worth the investment. (See Figure 4 and Table 20.) Improving the nozzles to require lower pressure, hence less energy, could provide as much as 10 percent energy savings. This approach, however, is 6-8 years in the future. ${ }^{20}$ Because 
Table 20

Pumping Energy Requirements for Different Irrigation Methods Using Groundwater ${ }^{a}$

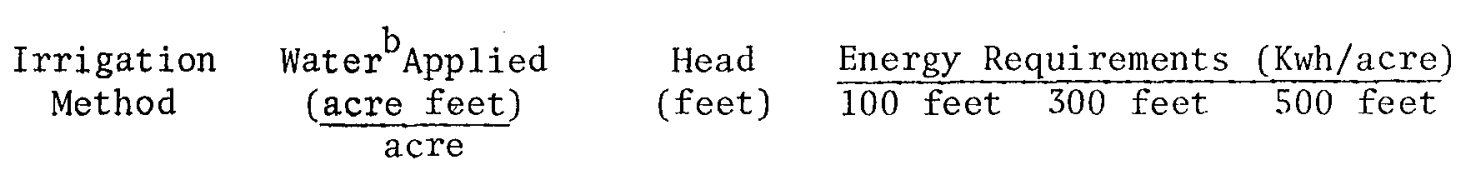

$\begin{array}{lrrrrr}\text { Furrow } & 3.0 & 0 & 558 & 1677 & 2793 \\ \text { Sprinkler } & 2.4 & 126 & 1010 & 1906 & 2798 \\ \text { Runoff-Reuse } & 2.4 & 20 & 513 & 1371 & 2226 \\ \text { Drip } & 1.5 & 46 & 571 & 1355 & 2136\end{array}$

\footnotetext{
assumes pump efficiency of 55 percent

$\mathrm{KWh} / \mathrm{AF}=1.024($ depth $/$ efficiency)

$\mathrm{KWh} / \mathrm{AF}=1.024$ (additional energy + depth/efficiency for head)

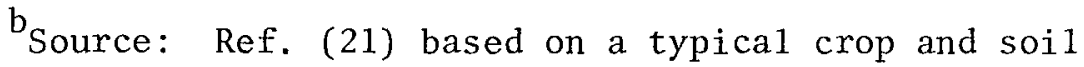




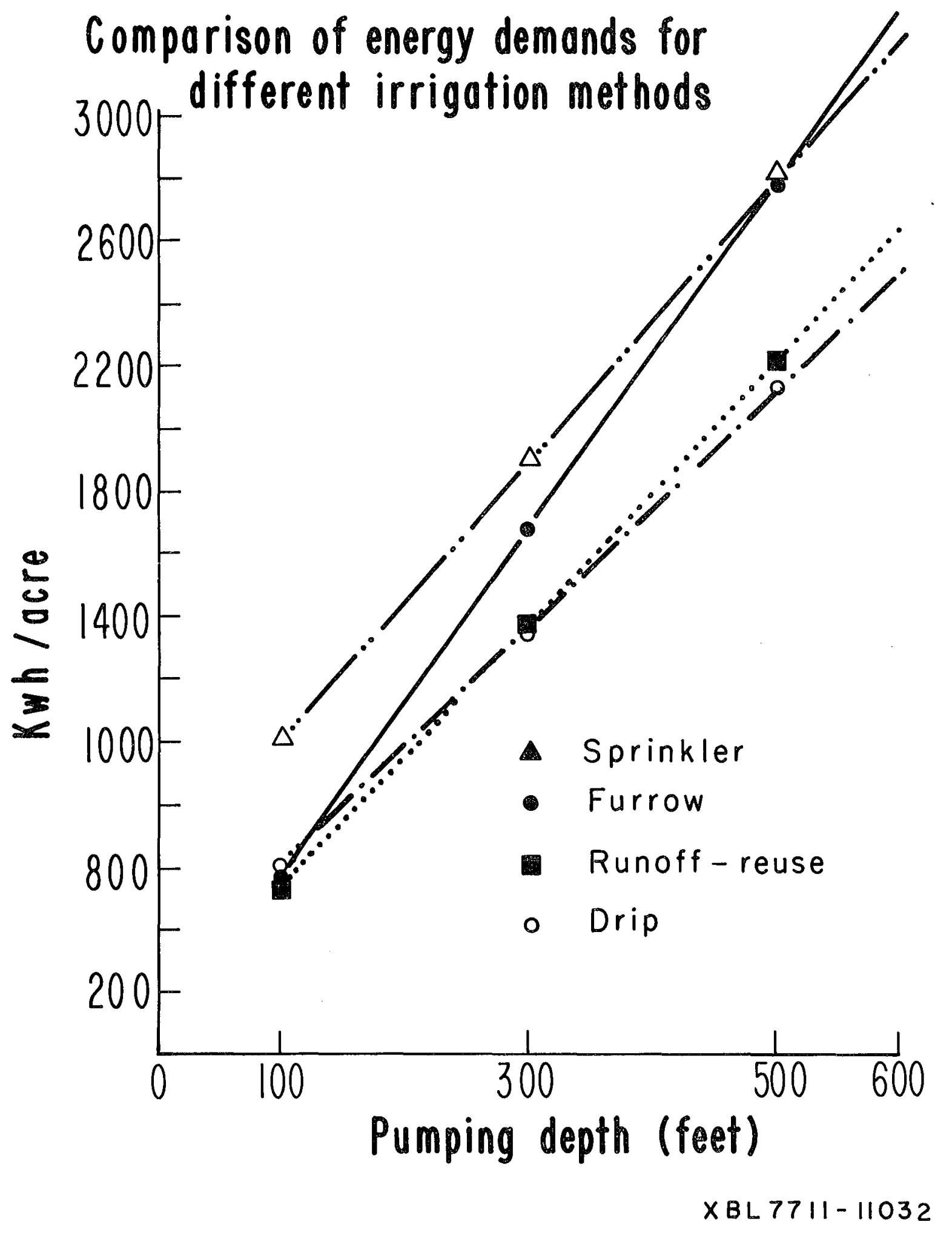

Figure 4. 
of the spray characteristics sprinklers are best used on coarse soils on $1 y$. In addition, the air borne water from sprinklers can increase plant disease incidence.

In drip irrigation, water trickles from an emitter in a pipe. The water must be filtered under slight pressure to prevent the emitters from becoming clogged. Drip irrigation requires a lower pressure than sprinklers, but its applicability is limited to widely-spaced crops. It cannot be used on soils of extreme coarseness or fineness. The timing of conversion to a drip system is crucial for perennials. It should be done during the fall or winter when the plants' water demand is low to allow new root growth in a smaller area near the emitter. The economic advantage to the farmer is greatest for high value crops such as trees and vines or where water is expensive because the installation and labor costs are also great.

Gated pipe contains the water as it flows and dispenses it at its point of application. This system allows greater area distribution of water from a single source than surface irrigation. It can be used on steep slopes where surface methods would cause erosion. The water in the pipe needs 1ittle additional pressure. As a result, gated pipe irrigation offers a much greater energy savings than sprinkler and drip systems. With automated control (see Irrigation Management Section below), as much as 50 percent energy savings can be achieved. 24

A11 these systems have the advantage of providing more uniform application of water than surface systems and more control for varying conditions in a field. Conversion to any of these systems takes time and money. The state legislature is now considering a bill to institute a tax credit for installing water-saving irrigation systems, but little can be done to reduce the time factor. An irrigation system takes time to design, order, de1iver, insta11, and adjust before any savings will be realized. Operating and maintaining a system requires additional labor which means more expense for the farmer (see Table 21).

The calculation of energy requirements for various irrigation systems using ground water (see Table 20 and Figure 4) has some unstated assumptions. Mechanical methods are contrasted with inefficiently 
Table 21

Cost Factors of Irrigation Systems

\begin{tabular}{|c|c|c|c|c|c|}
\hline $\begin{array}{l}\text { Irrigation } \\
\quad \text { Method }\end{array}$ & $\begin{array}{c}\text { Capital Cost } \\
\$ / \text { acre }\end{array}$ & Labor $^{a}$ & $\begin{array}{l}\text { Labor }{ }^{b} \\
\text { Cost } \\
\$ / a c / y r\end{array}$ & $\begin{array}{c}\text { Power Cost } \\
\$ / a c / y r \\
\text { (app1ication only) }\end{array}$ & $\begin{array}{c}\text { Average } b, c \\
\text { Annual } \\
\text { Cost } \\
\$ / \mathrm{ac} / \mathrm{yr} \\
\end{array}$ \\
\hline Surface Flood Systems & & $\begin{array}{l}\text { Intensive } \\
\text { but } \\
\text { infrequent }\end{array}$ & & & \\
\hline Graded border & $500-600$ & & $20-50$ & $0-5$ & $100-200$ \\
\hline Level border & $500-600$ & & $20-50$ & $0-5$ & $100-200$ \\
\hline Furrow & $400-500$ & & over 50 & $0-5$ & $200-300$ \\
\hline Sprinklex Systeins & & $\begin{array}{l}\text { Daily or } \\
\text { automated }\end{array}$ & & & \\
\hline Portable & $400-600$ & & over 50 & over 15 & $100-200$ \\
\hline Wheel Rol1 & $400-600$ & & $20-50$ & over 15 & $100-200$ \\
\hline Solid Set & $700-1200$ & & under 20 & over 15 & $200-300$ \\
\hline Center Pivot & $700-1000$ & & under 20 & over 15 & $200-300$ \\
\hline Boom (Giant) & $600-700$ & & $20-50$ & over 15 & $200-300$ \\
\hline Drip Systems & $500-1200$ & Automated & under 20 & $5-15$ & $200-300$ \\
\hline
\end{tabular}

${ }^{a_{\text {Reference }}} 21$, Figure I, p. 63.

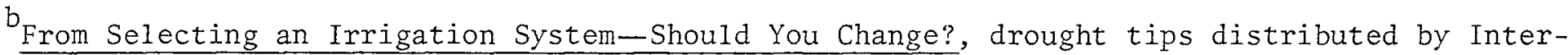
agency Agricultural Information Task Force.

${ }^{c}$ Amortized capital cost plus operating and maintenance cost. 
operated surface types. If surface methods which incorporated cutback irrigation were used in the comparison, the savings would be less. A1so surface methods do not require expensive equipment or make money for manufacturers. Finally, it is assumed that the rate of water application is constant for a given irrigation method.

Irrigation Management

There are three distinct aspects to irrigation management: measurement, scheduling and operation. In order to determine the amount of water to apply, it is necessary to know the water that is available to the crop and the water needs of the crop. Measuring the soil moisture tension or the water budget between evaporation and precipitation provides information about the former and the growth stage dictates the latter. A water budget supplies an estimate of how much water has been transpired or evaporated since the last measurement by determining how much water has evaporated from a pan. This method is easy and inexpensive but it requires skill and experience in interpreting the data. A direct and easy way to assess the soil moisture level is to probe the ground each foot for the first five ieet and estimate the depletion by feeling the soil. With very little experience such measurements can be accurate to the tenth of an inch. Obtaining ground truth by moisture tension measurement requires more complex instrumentation which less convenient for the farmer to use. The slow release of soil moisture by clay soils makes these latter two nnethods somewhat more reliable for calculating water application in California.

Another necessary measurement for irrigation management is water flow rate, which is also used in measuring pump and well efficiencies. Water use can be reducer by eliminating the error in the amount of application, which can be off by $20-40$ percent. ${ }^{23}$ This requires the installation of a meter and the effort to use it.

The scheduling of irrigation depends on water use rate and the irrigation strategy. Irrigation at full field capacity requires heavier, more frequent applications than irrigation to balance the evapo-transpiration (ET). Though ET balance irrigation does use less water than field capacity irrigation, the crop yields are equal. 30 
An amount of flexibility can be achieved even with manually operated systems. Cutback irrigation in a gravity fed system consists of initially flooding the furrow using surplus hoses. When the entire length is wetted, only those hoses needed to maintain the system are left in place. In this manner most of the water applied goes into the soil rather than running off as it would if the initial stream were maintained throughout irrigation.

While measurement and scheduling. techniques definitely benefit the farmer in conserving water, they are unfamiliar and require some training and experience to use. Services are available which will supply the information needed to set up an irrigation program. Field measurement of soil moisture is. necessary in any climate in order to determine water need. But in dry growing season areas such as California, computer analysis of meteorological data is unnecessary. At the moment there is a shortage of trained personnel in irrigation management so that the expansion of this practice will be limited for the next few years. Another possible approach would be to disseminate to farmers the basics of measurement and schediling so that they could undertake their own irrigation management.

While irrigation management is often referred to in terms of water savings, it can a1so mean increased application where a farmer has been under-irrigating. If a farmex does not take into account an initially low soil moisture level, water applications wil1 not be sufficient for a good crop if they are scheduled only to replace subsequent depletion. However, because plants show stress and will be damaged when dehydrated, under-irrigation is less common than over-irrigation. When under-irrigation does occur, applications tend to be close to the optima1. level. With over-irrigation, applications may greatly exceed the optimum since the excess will drain off or percolate down.

Irrigation management does require labor inputs and often capital inputs as well. However, the potential savings are substantial enough to make it worth consideration. A savings of 25 percent of the energy 
used in pumping can be realized while maintaining yields. In addition, an estimated 35-40 percent water savings will become increasingly important as resource prices rise. ${ }^{20}$ A summary of survey responses in Appendix A shows the extent, though not the amount, of water savings with irrigation management and growers reactions to I.M.S.

There must be planning of water delivery at the district leve1 which accounts for different crops and different types of irrigation systems to implement irrigation management. In order to encourage more efficient water use, pricing policy should be changed from a fixed rate to a graduated scale, since a fixed rate may encourage farmer to use the full amount paid for.

Institutional Factors Affecting Conservation

While conservation practices occur on the farms and in the water districts, their implementation draws on institutional structures and policies. Among those institutional settings which affect water use are:

- appropriative water rights law

- water quality standards

- water resource development

- definition of efficient and beneficial use

- pricing structure

- information services

Appropriative Water Rig?ts Law

Water rights in California are based on actual use. This is commonly interpreted to mean "use it or lose it" and many farmers maintain wasteful practices in the belief that establishing use will serve as a hedge against future water needs. However, the law states that use must be beneficial and reasonable. If a use is shown not to meet this criteria, the user stands to lose the excessive amount. Currently there is 1ittle enforcement by the State. Most investigations are being done on the basis of complaints. 
Water Quality Standards

While to some degree these standards limit the availability of water and affect the cost (see Using Reclaimed Waste Water), generally they serve to promote minimal leaching by keeping the salt levels down. in both the in flow and out flow of water through the soil. 31

\section{Water Resource Development}

In the physical sense the current system's structure affects the water delivery schedule due to its capacity and delivery time requirement. In a societal sense, the agencies involved with water resources can plan development to increase supply or to use more efficiently supplies available. One of the major tools implementing this latter policy is water pricing (see below). Because of the amount of electricity needed to deliver water by CVP and SWP ( 2 billion Kwh in 1972 compared to 3.3 billion Kwh for all on-farm pumping), ${ }^{21}$ curtailed use of surface water could result in energy savings, depending on local water availability.

Definition of Efficient and Beneficial Use in Water Conservation Policy

Though much of this issue is very subject to differences of values between factions, certain aspects can be and need to be better defined. Current1y many farmers estimate water applied and may be off by 20-40 percent. $^{23}$ Metering water flows would establish how much water is being used in irrigation. Another aspect in evaluating efficiency is to determine the amount of water needed. A great difficulty here is the extent to which that can vary with factors of time and region.

Pricing Structure

Cost per acre-foot for surface water is one-half to one-tenth the cost of pumping ground water, at the rates charged by the water agencies. These rates are subsidized. In some water districts the rates are structured so that the more water used, the lower the cost per acre-foot. In others there is one initial charge for using water up to a certain amount. This latter pricing practice encourages farmers to use that full amount irrespective of actual need because they have paid for it. 
When excessive surface water is applied, the percolating water recharges the aquifer. The raised water table makes the cost of pumping from private we11s less than in normal conditions. The result is essentially that surface water is made accessible though these wells, though their operators do not pay for water delivery. ${ }^{32}$

Raising the price for use of surface water above a minimal amount has been suggested as an incentive for water conservation. ${ }^{21}$ No longer subsidizing water prices for agriculture would allow other users such as industry and power generation to compete economically for use of water resources and would force farmers to use water more efficiently. While it has been noted earlier in this paper that there is water wastage which can be eliminated, marginal pricing for irrigation water inadequately addresses two major issues in irrigation: What is efficient water use once waste has been eliminated and how should minimum water use be determined? Yield and crop quality generally are directly related to the amount of water applied. More than crop survival is needed by the farmer for economic survival. Crops must meet certain quality criteria to be marketable at various grades. And there are some established costs such as pest control that remain relatively constant regardless of yield, so that maximum yield makes the most efficient use of them. Due to variations in growing conditions, it is impossible to establish a universal minimum. Determination of local minimum would require greatly expanded and improved data collection for crop, soil type, weather, topography, etc. If the price of water above any minimum were to become greater than the cost of pumping ground water, such a rate structure may lead to the aggravation of ground water depletion. To avoid this result, both gound and surface water availabilit $y$ must be incorporated in water conservation policy. These factors need to be balanced with the farmers'profit margin.

Information Services

Making information about conservation practices available to the farmer will facilitate their implementation. Such services currently are 
in operation on various levels. There are private consulting firms which can advise the farmer on all phases of field operations. At the state level, the agricultural extension in each county offers information and help to improve farming practices. This service requires that the farmer request such information or help. The U. S. Bureau of Reclamation has an Irrigation Management Service which involves both individua1 farmers and water districts. These services act to better the farmers' situation without explicitly incorporating relationships between the agricultural sector and others. Some effects may be beneficial in a broader way and others may not. These services also operate on the existing infrastructure, such as water delivery systems, irrigation techniques, labor relations, market conditions, and environmental quality standards.

The planning agencies should be concerned with issues related to the above mentioned infrestructure. It is they who are the other major client for information services. However, the nature of the information they require is broadly based and comprehensive in order to have a sound basis for policy formulation. While good information on some issues arises, there are serious gaps. This situation is discussed in the following section.

Research Needs for Agricultura1 Conservation

There is some information currently available on agricultural use of water and electricity. Many studies are concerned only wi.th one or two factors. Factors, such as water sources, are not differentiated. In other studies, the aggregation of data makes it difficult to understand the relationships between various factors. The statewide average of pump efficiency and of pumping lifts are not exact enough to allow calculation of potential energy savings for pump maintenance. In order to formulate more effective and realistic water and energy conservation policy, there are a number of research questions which must be investigated:

- What is the actual correlation between irrigation practices (method and efficiency) and water source, surface or ground and their associated costs? In Figure 4 and Table 20, we have shown 
The relationship between electricity use, water depth and irrigation method. What is the actual use situation? We need to know this to make any projection of potential energy savings through irrigation management.

- What is the relationship between cropping pattern and water availability? It has been shown that for field crops there is a genera1 trend to use less water-consumptive crops where water costs more. 11 How does the market affect assessment of water cost? At what point does the limit of water availability affect cropping patterns?

- How will water conservation practices affect other cultivation practices? To what extent will they increase or decrease the use of fertilizers, pesticides and herbicides? Less water applied may mean these chemicals wont be washed away as quickly so less may be needed. Since fertilizer alone requires more energy for production than all the electricity used in irrigation pumping, reduced fertilizer application will result in energy conservation external to farm operations.

- How much flexibility is there in scheduling water delivery? Between what soil moisture levels is it beneficial and efficient to irrigate? How much can deliveries be gauged?

- What are the benefits and costs of water conservation? What use opportunities may be foregone in favor of another use? Pricing policy may depend on this question. How does conservation or its lack affect water quality? In reusing water, does actual water quality meet the standard required for a particular use? How much energy is required to treat and transport the water? Some work has been done on the tradeoffs between water consumed and its electricity generating capacity. ${ }^{7}$ This has not included the pumping energy required to substitute ground water for surface water. In order to analyse the effects of such substitution, an examination of ground water reserves and their depths by local area is necessary as well as the transport energy for surface supplies. 
- How much electricity can be conserved by improving pump efficiencies? This depends on the lift and volume of water being pumped, factors which vary from locality to locality. The aggregated data available $e^{6}$ has 1 imited use since depths and use must be matched at least within water table areas.

- What effect do practices in associated sectors such as food processing and food preservation methods have on cultivation practices? The farmer has certain1y altered the crop varieties grown to fit in with packing and marketing practices, but without regard to these varieties water and energy requirements.

Prospects for Conservation

In the agricultura1 sector, conserving water and conserving energy are complexly related. While energy may be conserved independently of water, as in pump and wel1 efficiencies, for the most part energy is used directly or inversely proportional to water use. In this abstracted context, it is possible to budget water and energy use, even with regional variations of soil, topography and water availability. In actuality, other factors such as labor, time and capital outlay play a major role in the farmer's estimation of the feasibility and profitability of implementing conservation strategies. The decisions of individual farmers about water and energy conservation are made within the institutional structure of water district operations, water agency policy, state and federal water quality standards and water rights laws. These structures affect the farmers evaluation of conservation in terms of what is feasible and what are the benefits and costs involved.

The treatment of conservation in this paper leans toward strategies that can be implemented immediately. While conservation is clearly both necessary and possible, there needs to be better understanding of the impact of practices on the local ecological conditions. What may be a sound practice in one area, may waste energy and/or disrupt the local ecology in another area. Again, care must be taken in recommending any course of action. Criteria should be outlined so that the farmer understands the extent to which a particular conservation practice 
applies to his area. Specific actions which would facilitate conservation are establishing programs for irrigation record keeping, pump testing and well testing; gaining acceptance for alternative energy sources and irrigation management through explaining and demonstrating their benefits to farmers; encouraging irrigation districts to foster efficient water use, to maintain supplies through canal lining and to generate power where possible.

In formulating policy more information is needed of actual practices, conservation implementation, regional variations of growing conditions and the linkages between these. This information would enable policy to be more realistic about what is possible, what is desirable and what is necessary and thereby more effective. Finally, further research on potential for energy and water conservation in agriculture can give a clearer idea of how agricultural resource use fits into the social matrix of resource use and would aid in making policies for various sectors compliment each other. 
APPENDIX A

In order to gauge the effect of the Irrigation Management Service (IMS) program, USBR runs a survey of those growers on the program. Some of the results are compiled in Table A-1. The E1 Dorado Irrigation District (EID) sample shows better compliance with the program as we11 as greater satisfaction and desire to continue on it than the Solano Irrigation District (SID) sample. Some of this more positive response to IMS may be the result of those who support IMS being more likely to return their questionnaires. The response rate for EID is much lower than SID. In turn, this support of IMS may result from greater improvement. EID has more widespread water savings.

It must be remembered that these responses are to conditions of an abnormal year. There are at least two points where the drought situation may be reflected in the growers responses. While EID did have more widespread water saving, to some extent this was due to the strict rationing implemented during the 1977 growing season. Scarcity of water supply will remain an issue at EID because plans to increase water supply severely lag behind the increasing demand. The lack of improvement in crop yield and quality for EID (1977) comes from this rationing situation. Supply was so short that water was allocated for minimum crop and tree survival.

While the field technicians, who take measurements and dispense irrigation scheduling recommendations, are knowledgeable and competent in their jobs, the extent to which they are seen as being helpful relates to the success of the program. Suggestions for improving service indicate what qualities constitute helpfulness; more frequent visits, less turnover in personnel, and better training especially in field experience. Other suggestions are presenting the soil moisture information in a better way and not offering more elaborate service.

The information presented here compares IMS in two locations. Unfortunately, at present there is no data available for comparing water use on and off IMS. The "results" presented in Table A-1 do not indicate the amount of water saved, just the growers estimation of one year's 
water application compared to what is thought to be usual. As can be seen, documentation for these results is spares. Having accurate records of water application would aid greatly is assessing the usefulness of IMS. 
Table 22

A-1

Comparison of Resu1ts of Irrigation Management Service (IMS) Questionnaire by Irrigation District and Year

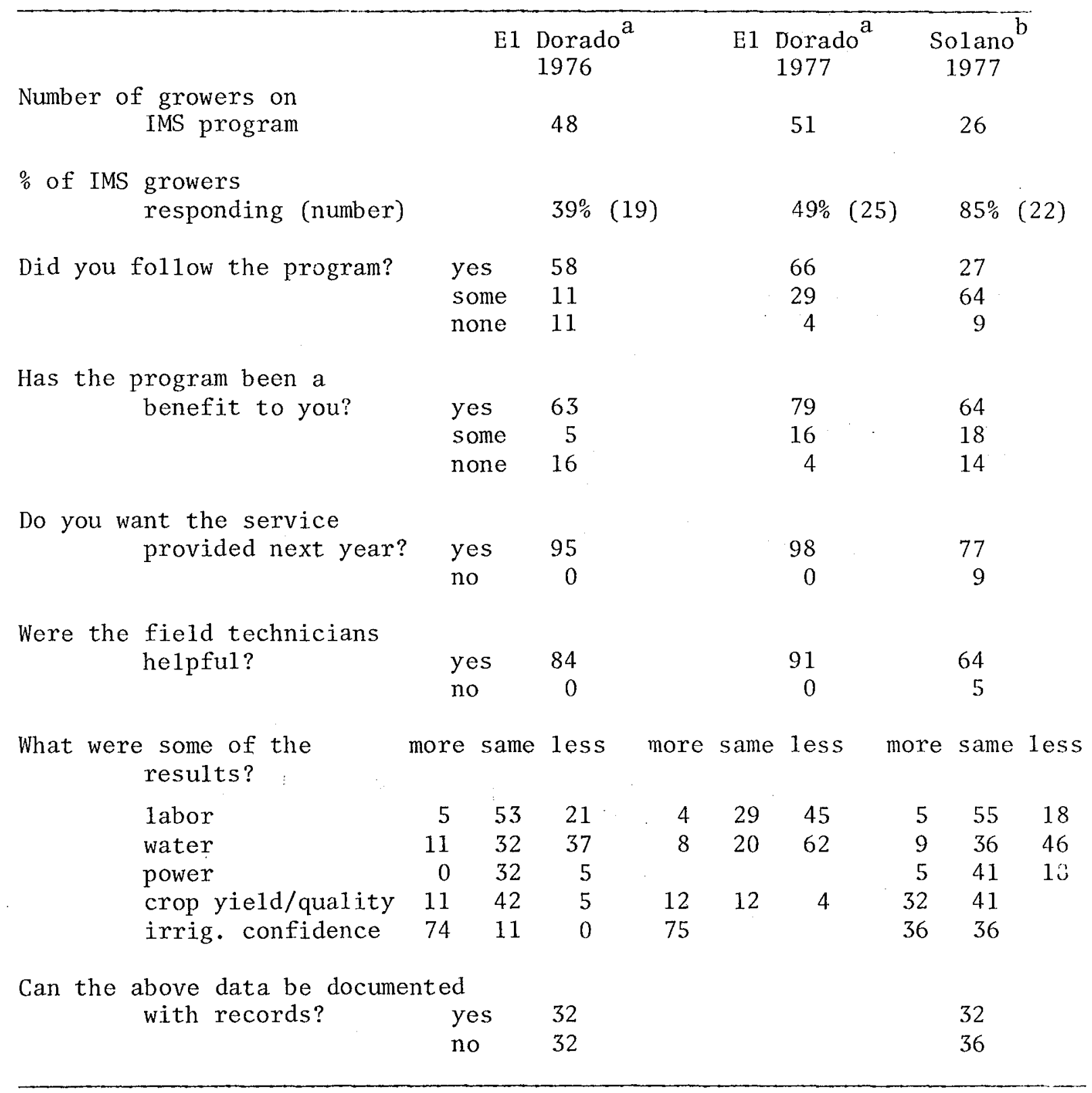

Al1 figures in percentage of respondent except where noted. 


$\begin{array}{lcc}\text { E1 } \text { Dorado }_{1976}^{a} & \text { E1 } \text { Dorado }^{a} & \text { Sol ano }^{b} \\ 1977\end{array}$

Would you recommend this service to others?

yes

no

84

0

73

9

Would you prefer a more detailed service?

yes

no

yes

no

29

amounts required:

irrigation system

evaluation:

yes

no

12

29

more probe sites:
36

46 yes

no

a. Source: C. Applegate, E1 Dorado Irrigation District, unpublished data, August 1978 .

b. Source: G. Lyford, U.S.B.R. Sacramento, unpublished data, August 1978. 


\section{REFERENCES}

1. J. Sathaye et a1., Effects of the Drought on Ca1ifornia E1ectricity Supply and Demand, LBL-6356, Lawrence Berkeley Laboratory, June 1977.

2. J. Sathaye et a1., Potentia1 Electricity Impacts of a 1978 Ca1ifornia Drought, LBL-6871, Lawrence Berkeley Laboratory, January 1978.

3. Ca1ifornia Department of Water Resources, The Continuing Ca1ifornia Drought, August 1977.

4. California Department of Food and Agriculture, Projected 1977 California Agricultura1 Drought Report, August 1977.

5. Ca1ifornia Department of Water Resources, "The Ca1ifornia Water P1an: Outlook in 1974," Bulletin No. 160-74, November 1974.

6. G.D. Knutson et a1., Pumping Energy Requirements for Irrigation in California, Division of Agricultural Sciences, Special Publication No. $3215,1977$.

7. E.B. Roberts and R.M. Hagan, Energy Requirements of Alternatives in Water Supply, Use and Conservation: A Preliminary Report, Contribution No. 155, California Water Resources Centex, University of Ca1ifornia, Davis, 1975.

8. R.M. Hagan and E.B. Roberts, Energy Requirements of Alternatives in Water Supp1y, Use and Conservation and Water Quality Controls with Emphasis on Central Valley and Delta Area, unpublished semi-annual report to Lawrence Livermore Laboratory, 1976.

9. D. Dvoskin and E.D. Heady, Energy Requirements of Irrigated Crops in the Western United States, Center for Agricultural and Rural Development, Iowa State University, Ames, Towa, November 1976.

10. California Department of Water Resources, Water Conservation in California, Bulletin No. 198, May 1976.

11. J. Ian Stewart, Irrigation in California, Report to State Water Resources Control Board, June 1975.

12. Personal Communication, U.S. Bureau of Reclamation, Central Valley Project, October 1977.

13. Personal Communication, California Department of Water Resources, October 1977.

14. U.S. Department of Agriculture, California Crop and Livestock Reporting Service, Principa1 Crop and Livestock Commodities-1975, June 1976.

15. U.S. Department of Agriculture, California Crop and Livestock Reporting Service, Principal Crop and Livestock Commodities-1976, June 1977. 
REFERENCES (continued)

16. U.S. Department of Agriculture, California Crop and Livestock Reporting Service, Crop Intentions Report, June 1977.

17. U.S. Department of Agriculture, California Crop and Livestock Reporting Service, Ca1ifornia Fruit and Nut Statistics (1975-76), February 1977.

18. U.S. Bureau of Reclamation, Preliminary Operating Plans for 1978: Central Valley Project, September 1977.

19. California Department of Water Resources, Operational Criteria for the State Water Project-December 1, 1977-December 31, 1978, Draft Report, September, 1977.

20. U.S. Energy Research and Development Administration, Division of Industrial Energy Conservation, Report of the Proceedings of the ERDA Workshop on Energy Conservation in Agricultural Production, Washington, D.C., July 15-16, 1976.

21. California Department of Water Resources and University Coperative Extension Service, Agricultural Water Conservation Conference Proceedings, June 23-24, 1976.

22. California, Governor's Office of Emergency Services, Community Water Management for the Drought and Beyond: A Handbook for Local Government, May 1977.

23. Nebraska Center for Continuing Education, Irrigation Short Course Proceedings, January 24-25, 1977.

24. Nebraska Water Resources Research Institute, The Role of Water in the Energy Crisis, proceedings of a conference held October 23-24, 1973 in Lincoln, Nebraska.

25. Roberts, E., U.C.Davis, persona1 communication, October 1977.

26. Hagan, R., U.C.Davis, personal communication, October 1977.

27. Stetson, L.E. et al., "Irrigation System Management for Reducing Peak Electrical Demands," Transactions of the American Society of Agricultural Engineers, Volume 18, Number 2, 1975, pp.303-11.

28. Water Industry's Power Use Survey: Preliminary Analysis, August 1977.

29. Davies, J.W., Mulching Effects on P1ant C1imate and Yield, World Meteorological Organization, Technical Note No. 136, 1975.

30. Hounam, C.E. et a1., Drought and Agriculture, World Meteorologica1 Organization, Technica1 Note No. 138, 1975.

31. Willey, Z., Summary of the Environmental Defense Fund's Testimony on the Proposed Water Conservation Policy, Guidelines and Reasonable and Unreasonable Uses, State Water Resources Control Board and California Water Commission, January 31, 1977.

32. Lyford, G., U.S.B.R., Sacramento, personal communication, July 1978 
This report was done with support from the Department of Energy. Any conclusions or opinions expressed in this report represent solely those of the author(s) and not necessarily those of The Regents of the University of California, the Lawrence Berkeley Laboratory or the Department of Energy. 
TECHNICAL INFORMATION DIVISION LAWRENCE BERKELEY LABORATORY UNIVERSITY OF CALIFORNIA BERKELEY, CALIFORNIA 94720 